\title{
BIARLAH ORANG MATT MENGUBURKAN ORANG MATI Investigasi Latar Kultural Matius 8:21-22/Lukas 9:59-60
}

\author{
Deky Hidnas Yan Nggadas \\ Sekolah Tinggi Teologi Huperetes, Batam, Indonesia \\ Email: deky_nggadas@yahoo.com
}

\begin{abstract}
The text of Matthew 8:18-22 and its parallel in Luke 9:57-59 contain a deep meaning and also requires exegetical attention to find the meaning. The reason to finding meaning in the texts was due to differences of opinion about the background, such as the cultural aspect behind disciple's reason for "going to bury my father first" and the purpose of Jesus's response: "let the dead buried their people". The context is closely related to Jewish burial tradition (known as liqut 'azamot or ossilegium). However, on the other hand, responsibility to caring parent who died was part of the fifth commandment in Dekalog: "Respect your father and mother."
\end{abstract}

Key words: cultural aspects, burial traditions, liqut 'azamot, ossilegium

\section{ABSTRAK}

Teks Matius 8:18-22 dan paralelnya yakni Lukas 9:57-59 mengandung makna yang mendalam dan membutuhkan perhatian eksegetis untuk mendapatkan makna tersebut. Alasan mendapatkan makna pada teks-teks tersebut disebabkan adanya perbedaan pendapat mengenai latar belakangnya, termasuk aspek kultural di balik alasan sang murid untuk "pergi dahulu menguburkan ayahku" dan maksud dari respons Yesus, "biarlah orang mati menguburkan orang-orang mati mereka". Konteks tersebut terkait erat dengan tradisi penguburan dalam

lingkungan Yahudi (disebut dengan liqut 'azamot atau ossilegium). Namun, di sisi lain, tanggung jawab mengurus orang tua yang meninggal merupakan bagian dari perintah kelima dalam Dekalog: "Hormatilah ayahmu dan ibumu."

Kata-kata kunci: aspek kultural, tradisi penguburan, liqut 'azamot, ossilegium

\section{PENDAHULUAN}

Beberapa waktu yang lalu, kami sekeluarga membaca Matius 8:18-22 dalam saat teduh pada malam hari. Sebagaimana saat teduh pada umumnya, tendensi kami adalah mendapatkan pelajaran rohani dari bagian ini. Saat mendiskusikan isinya, kami segera sadar bahwa tidak mudah untuk menarik aplikasi dari Matius 8:21-22 karena ungkapanungkapan yang terdapat di dalamnya tidak familiar bagi kami. Sebenarnya, pada siang harinya saya sudah melakukan "riset kilat" dengan membaca beberapa buku tafsiran.
Saya mendapati bahwa usulan-usulan mengenai latar belakang ungkapan-ungkapan itu tidak seragam. Dalam saat teduh itu, karena belum bisa memutuskan pandangan mana yang representatif untuk dianut, saya berjanji kepada istri dan anak-anak saya untuk meneliti lebih lanjut mengenai ungkapanungkapan tersebut kemudian mendiskusikannya kembali dengan mereka setelah selesai. ${ }^{1}$

\footnotetext{
${ }^{1}$ Pengalaman mengunjungi berbagai Gereja dan mendengarkan khotbah-khotbah di berbagai Gereja
} 
Berangkat dari konteks di atas, saya melakukan riset dan mengembangkan secara detail mengenai latar kultural dari teks Matius 8:18-22/ Lukas 9:57-59. Artikel ini didahului dengan menjelaskan masalah-masalah eksegetis dan fokus penelitian, kemudian dilanjutkan dengan pembahasan kedua yaitu "hormatilah ayahmu dan ibumu; pembahasan

yang berbeda pula di Indonesia, saya melihat bahwa mayoritas khotbah disiapkan dengan tendensi aplikatif semata tanpa dasar eksegetis yang solid untuk penarikan aplikasi tersebut. Saya melihat - sesuatu yang sebenarnya sangat memalukan untuk disampaikan di sini - bahwa mayoritas Pendeta mempersiapkan khotbah tanpa melakukan eksegesis sama sekali. Itulah sebabnya, saya perlu memberikan penandasan tajam di sini bahwa untuk keperluan apa pun (khotbah, saat teduh, PA, dsb.), riset eksegetis harus tetap menjadi fondasi untuk penarikan aplikasi atau implikasi atau kontekstualisasi dari Firman Tuhan. Tanpa melakukan eksegesis terlebih dahulu, hampir pasti bahwa kita akan menarik aplikasi yang salah karena sebenarnya kita sedang memasukkan gagasan kita sendiri ke dalam Alkitab kemudian kita menganggap bahwa gagasan kita itu sama dengan apa yang dimaksudkan penulis Alkitab. Kita harus mengingat dengan jelas bahwa Alkitab memang dituliskan bagi [for] kita, namun tidak dituliskan pertama kali untuk [to] kita. Alkitab pertama kali dituliskan untuk orang-orang pada jaman tertentu, yang karenanya pengenalan kita akan konteks jaman itu merupakan keharusan yang tidak bisa digantikan hanya dengan satu mangkuk perenungan di kamar terkunci. Kita harus menerapkan prinsip-prinsip eksegetis yang tepat untuk mendapatkan kesimpulan eksegetis yang tepat pula yang di atasnya kita meletakkan aplikasinya bagi kita. Grant R. Osborne menulis, "Sementara berita Injil itu sederhana, tugas untuk menyingkapkan makna sebuah teks spesifik begitu rumit dan menuntut kerja keras. Kita hanya dapat memenuhi tanggung jawab yang besar ini tatkala kita membangun dan menerapkan hermeneutik yang konsisten" (The Hermeneutical Spiral: A Comprehensive Introduction to Biblical Interpretation $\left[2^{\text {nd }}\right.$ edition; Downers Grove, Illinois: IVP Academic, 2006], 24). William B. Tolar menulis, "Gagal untuk menggunakan aturan-aturan gramatikal yang tepat atau mengabaikan konteks-konteks historis [Alkitab], merupakan jaminan yang paling pasti untuk kegagalan kita memahami maksud para penulis Alkitab" ("The Grammatical-Historical Method," in Biblical Hermeneutics: A Comprehensive Introduction to Interpreting Scripture, eds. Bruce Corley, Steve W. Lemke, and Grant I Lovejoy [ $2^{\text {nd }}$ edtion; Nashville, Tennessee: Broadman \& Holman Publishers, 2002], 21). Dalam buku saya yang terbaru, saya sudah memberikan beragam alasan mengapa eksegesis itu merupakan suatu urgensi dan keharusan, lih. Deky Hidnas Yan Nggadas, Paradigma Eksegetis: Penting dan Harus (Depok: Indie-Publishing, 2013), 25-42. ketiga, sejarah eksegesis dengan menyuguhkan beragam pandangan, mencakup Ayahnya Belum Meninggal dan Ayahnya Baru Saja Meninggal; pembahasan keempat adalah respons Yesus yang mencakup metafora mengenai orang-orang non percaya, resistensi terhadap Taurat, retroversi: hipotesis Aramaik dan Ibrani, dan motif "nazir" dan "kerabat fiktif"; pembahasan kelima, komentar evaluatif; pembahasan keenam, tradisi penguburan Yahudi yang mencakup praktik Liqut 'Azamot atau Ossilegium dan menjawab keberatan, sebuah probabilitas abduktif. Dan diakhiri dengan signifikansi studi ini serta kesimpulan.

\section{MASALAH-MASALAH EKSEGETIS DAN FOKUS PENULISAN}

Sejauh yang saya amati, Matius 8:18-22 dan paralelnya dalam Lukas 9:57-59 mengandung beberapa masalah yang perlu mendapat perhatian eksegetis.

Pertama, perbedaan dalam hal urutan naratifnya. Matius 8:18-22 adalah lanjutan dari pengisahan Matius mengenai Yesus menyembuhkan mertua Petrus dan orangorang lain (8:14-17; kisah ini ditempatkan Lukas dalam ps. 4:38-41; Mrk. 1:29-34). Selanjutnya, diikuti dengan narasi tentang Yesus meredakan angin rebut (8:23-27; kisah ini ditempatkan Lukas dalam ps. 8:22-25; Mrk. 4:35-41). Berbeda dari urutan ini, Lukas mengisahkan tentang hal mengikut Yesus setelah sebuah narasi singkat mengenai Yesus dan orang Samaria (9:51-56) dan melanjutkannya dengan catatan mengenai Yesus mengutus 70 orang murid (10:1-12). Bila narasi "hal mengikut Yesus" adalah peristiwa tunggal, tentu kita harus mempertanyakan soal konteks original dari narasi ini, sebab tidak mungkin narasi tunggal ini terjadi dalam sekuensi (urutan) pengisahan yang berbeda seperti ini.

Kedua, perbedaan detail pengisahan. Dalam Matius 8:18-22 hanya dikisahkan mengenai interaksi Yesus dengan dua orang ("ahli Taurat" - ay. 18-20; dan "salah seorang murid Yesus" - ay. 21-22). Lukas 9:57-60 mengisahkan tentang interaksi Yesus dengan tiga orang mengenai hal mengikut Dia 
("seseorang di tengah jalan" - ay. 57-58, dari respons Yesus jelas bahwa orang ini adalah ahli Taurat yang disebutkan dalam Mat. 8:1820; "seorang lain" - ay. 59-60, paralel dengan "salah seorang murid-Nya" dalam Mat. 8:2122; dan "seorang yang lain lagi" - ay. 61-62, tidak terdapat dalam pengisahan Matius). Bila kita mengkhususkan perhatian terhadap "seorang murid-Nya", kita juga akan mendapati perbedaan verbatim yang saya garisbawahi dari pengisahan Matius dan Lukas, seperti yang tertera pada tabel di bawah ini:

\begin{tabular}{|l|l|}
\hline \multicolumn{1}{|c|}{ Matius 8:21-22 } & \multicolumn{1}{c|}{ Lukas 9:59-60 } \\
\hline $\begin{array}{l}\text { Seorang lain, yaitu salah } \\
\text { seorang murid-Nya, } \\
\text { berkata kepada-Nya: } \\
\text { "Tuhan, izinkanlah aku } \\
\text { pergi dahulu } \\
\text { menguburkan ayahku." }\end{array}$ & $\begin{array}{l}\text { Lalu Ia berkata kepada } \\
\text { seorang lain: "Ikutlah } \\
\text { Aku!" Tetapi orang itu } \\
\text { berkata: "Izinkanlah aku } \\
\text { pergi dahulu } \\
\text { menguburkan bapaku." }\end{array}$ \\
$\begin{array}{l}\text { Tetapi Yesus berkata } \\
\text { kepadanya: "Ikutlah Aku } \\
\text { dan biarlah orang-orang } \\
\text { mati menguburkan orang- } \\
\text { orang mati mereka." }\end{array}$ & $\begin{array}{l}\text { Tetapi Yesus berkata } \\
\text { kepadanya: "Biarlah orang } \\
\text { mati menguburkan orang } \\
\text { mati; tetapi engkau, } \\
\text { pergilah dan beritakanlah }\end{array}$ \\
& $\underline{\text { Kerajaan Allah di mana- }}$ \\
\hline
\end{tabular}

Perbedaan verbatim di atas telah memicu diskusi mengenai masalah autentisitas: pengisahan Lukas atau Matius yang autentik? ${ }^{2}$ Selain itu, identitas orang yang dikisahkan di sini pun tampaknya perlu diklarifikasi. Matius menyebutnya "salah seorang murid-Nya" [Yun. heteros ton matheton] dan ia menyapa Yesus dengan sebutan "Tuhan" [Yun. kyrie, vokatif tunggal dari kyrios], sedangkan Lukas menyebutnya secara umum "seorang yang lain" [Yun. heteron]. ${ }^{3}$ Dalam artikel ini,

${ }^{2}$ Lih. Martin Hengel, The Charismatic Leader and His Followers, trans. J.C.G. Greig, ed. J. Riches ( $2^{\text {nd }}$ edition; Edinburgh: T. \& T. Clark, 1996), 3-15; Thomas Walter Manson, The Teaching of Jesus: Studies in Its Form and Content (Cambridge: Cambridge University Press, 1967), 122; E.P. Sanders, Jesus and Judaism (Philadelphia: Fortress Press, 1985), 252-253;

Hal yang mengherankan adalah Matius menyebutnya sebagai salah seorang murid Yesus, namun mengapa ia justru diajak untuk mengikuti Yesus [bnd. Luk. 9:59]. Selain itu, perlu diinformasikan juga bahwa walaupun tidak disebutkan mengenai berdasarkan sebutannya dalam Injil Matius, saya menyebutnya dengan sebutan "murid", walau saya cenderung untuk menganggapnya sebagai seorang bakal murid. ${ }^{4}$

Ketiga, masalah pengaplikasian dari respons Yesus. Apakah respons Yesus yang sangat tajam itu hanya berlaku bagi sang murid tersebut saat itu ataukah bersifat normatif juga bagi setiap orang yang hendak mengikuti Dia?

Ketiga masalah di atas, termasuk eksegesis detail terhadap Matius 8:1822/Lukas 9:57-60 [atau lebih khusus Mat. 8:21-22/Luk. 9:59-60], tidak akan disentuh dalam artikel ini. Saya mempersilakan pihak lain untuk menangani masalah-masalah tersebut, bila dianggap perlu. ${ }^{5}$ Di sini, saya

identitasnya dalam pengisahan Matius dan Lukas, namun menurut Klemens dari Aleksandria, murid yang dimaksud di sini adalah Filipus. Lih. W.D. Davies and Dale C. Allison, Jr., A Critical and Exegetical Commentary on the Gospel according to St. Matthew: A Commentary on Matthew 8-18 (ICC; Edinburg: T. \& T. Clark, 2001), 53-54; Robert H. Gundry, Matthew: A Commentary on His Handbook of Mixed Church Under Persecution $\left(2^{\text {nd }}\right.$ edition; Grand Rapids, Michigan: Eerdmans, 1994), 153. R.T. France dalam tafsiran terdahulunya menyatakan bahwa orang ini jelas adalah seorang murid berdasarkan sapaan "Tuhan" yang digunakannya (Matthew [TNTC; Surabaya: Momentum, 2007], 160 - tafsiran ini pertama kali terbit pada tahun 1985). Namun, dalam tafsirannya yang lebih kemudian, ia memilih untuk menyebutnya seorang bakal murid, lih. R.T. France, The Gospel of Matthew (NICNT; Grand Rapids, Michigan: Eerdmans, 2007), 329; bnd. James D.G. Dunn, Christianity in the Making Volume 1: Jesus Remembered (Grand Rapids, Michigan: Eerdmans, 2003), 504. Sementara itu, Robert C. Mounce berpendapat bahwa sapaan "tuhan" yang digunakannya semata-mata merupakan sapaan hormat terhadap Yesus yang saat itu merupakan seorang guru yang sudah terkenal, lih. Matthew (Understanding the Bible Commentary Series; Grand Rapids, Michigan: Baker, 1991).

${ }^{4}$ Lih. catatan kaki no. 4.

5 Kedua masalah di atas, dalam hermeneutik, biasanya diteliti dalam rubrik perbandingan vertikal dan horizontal. Ulasan yang bersifat petunjuk mengenai cara melakukan perbandingan vertikal dan horizontal terhadap Kitab-kitab Injil, dapat dibaca dalam: Gordon D. Fee and Douglas Stuart, How to Read the Bible for All Its Worth: A Guide to Understanding the Bible ( $2^{\text {nd }}$ edition; Grand Rapids, Michigan: Zondervan, 1993), 132-139. Untuk terjemahan bahasa Indonesia dari buku ini: Hermeneutik: Bagaimana Menafsirkan Firman Tuhan dengan Tepat (Malang: Gandum Mas, 2006), 
akan memberi perhatian hanya pada masalah yang keempat, yaitu perbedaan pendapat tentang latar belakang yang tepat untuk memahami alasan sang murid dan respons Yesus terhadapnya (Mat. 8:21-22/Luk. 9:5960).

Seperti yang tertera pada sub judul di atas, fokus penulisan artikel ini adalah aspek kultural dari bagian ini. Atas dasar fokus penulisan ini, artikel ini ditulis dengan maksud menginvestigasi latar kultural di balik alasan sang murid untuk "pergi dahulu menguburkan ayahku" dan maksud dari respons Yesus, "biarlah orang mati menguburkan orang-orang mati mereka". Dalam artikel ini, saya akan berargumentasi bahwa latar belakang kultural dari ungkapanungkapan ini terkait erat dengan tradisi penguburan dalam lingkungan Yahudi saat itu, khususnya tradisi penguburan kembali tulang-tulang kerabat yang sudah meninggal sekitar satu tahun (liqut 'azamot atau ossilegium). ${ }^{6}$

Dalam rangka memenuhi tujuan di atas, saya akan menyajikan observasi saya terhadap beragam proposal dari para penafsir yang diakhiri dengan deskripsi dan argumentasi

121-128. Analisis vertikal dan horizontal, khususnya dalam menafsirkan Kitab-kitab Injil, merupakan salah satu manfaat dari menerapkan metode Kritik Redaksi, lih. Craig L. Blomberg, Jesus and the Gospel: An Introduction and Survey (Leicester: Apolos, 2002), 9395. Beberapa pendekatan lain juga dapat digunakan untuk mengamati perikop ini. Salah satu contoh analisis yang menggabungkan antara: kritik redaksi, kritik bentuk, dan kritik sastra, dan kritik retorika mengenai Matius 8:18-22/Lukas 9:57-60, dapat dibaca dalam: Stephen C. Barton, Discipleship and Family Ties in Mark and Matthew (Cambridge: Cambridge University Press, 1994), 140-155.

${ }^{6}$ Di internet, tidak banyak artikel ilmiah yang secara online bisa diakses. Sejauh yang saya ketahui, hanya ada satu artikel ilmiah yang ditulis mengenai aspek kultural di balik ungkapan-ungkapan dalam Matius 8:21-22/Lukas 9:59-60, yang ditulis oleh: Byron R. McCane, "Let the Dead Bury Their Own Dead': Secondary Burial and Matt. 8:21-22," in The Harvard Theological Review, Vol. 83, No. 1 (January 1990): 31-43. Hingga penulisan artikel ini, saya belum bisa mengakses dan membaca isi artikel McCane. Namun melihat dari sub judul artikelnya, saya menduga bahwa kesimpulan McCane tidak berbeda dengan pandangan yang saya anut dan kemukakan dalam artikel ini. saya mengenai aspek kultural yang [kemungkinan besar] melatarbelakangi Matius 8:21-22/Lukas 9:59-60. Sebelumnya, saya perlu memberikan penjelasan ringkas mengenai tanggung jawab mengurus orang tua yang meninggal yang sebenarnya merupakan bagian dari perintah kelima dalam Dekalog: "Hormatilah ayahmu dan ibumu".

\section{"HORMATILAH AYAHMU DAN IBUMU"}

Karena masalah yang diangkat oleh si murid yang beralasan itu berkenaan dengan mengurusi ayahnya yang meninggal, kita perlu melihat bobot dari alasan ini dari aspek keharusan dan urgensinya.

Pertama-tama, kita mesti memahami bahwa bagi orang-orang Yahudi, superioritas etnis [sebagai bangsa pilihan] tidak dapat dipisahkan dari masalah garis keturunan atau kekerabatan. Pendefinisian diri mereka sebagai orang Yahudi beririsan langsung dengan isu mengenai keluarga. James $G$. Crossley menulis, "jika masalah etnis begitu penting, maka keluarga dan hubungan darah memainkan sebuah peran penting dalam pemikiran Yahudi awal". 7 Pementingan akan kekerabatan atau garis keturunan dalam konteks Yahudi, dibangun atas dasar perintah kelima dalam Dekalog, yaitu "Hormatilah ayahmu dan ibumu" (Kel. 20:12; Ul. 5:16). Josefus menulis,

Taurat menetapkan juga, bahwa orangtua harus dihormati tepat sesudah hormat kepada Allah sendiri, dan mengajarkan bahwa anak yang tidak membalas kebaikan yang telah ia terima dari mereka, dan memperlakukan mereka dengan tidak layak pada situasi tertentu, harus dilempari dengan batu [sampai mati]. Diajarkan juga bahwa seorang muda harus menghormati yang tua, karena Allah sendirilah yang tua dari segala sesuatu (Against Apion II.28). ${ }^{8}$

7 James G. Crossley, The New Testament and the Jewish Law: A Guide for the Perplexed (New York: T. \& T. Clark International, 2010), 90.

8 Flavius Josephus, Josephus: The Complete Works (Grand Rapids, Michigan: Christian Classics Ethereal Library, n.d.), 1602. 
Kata-kata Yosefus di atas menggemakan baik isi perintah kelima di atas maupun isi Keluaran 21:17 yang menetapkan hukuman mati bagi anak yang mengutuki orangtuanya.

Sampai pada masa Yesus, "Dari antara semua bentuk tugas yang diharuskan dalam hal menghormati orangtua, yang [dianggap] paling mendasar adalah penguburan orangtua yang meninggal." Tanggung jawab untuk menguburkan secara layak orang tua yang meninggal berakar dalam Dekalog karena dianggap oleh orang-orang Yahudi sebagai bagian dari "Hormatilah ayahmu dan ibumu" (Kel. 20:12). Hal ini ditegaskan oleh Craig S. Keener yang menyatakan bahwa orang-orang Yahudi menganggap hormat kepada orangtua sebagai perintah yang agung dan menguburkan orangtua secara layak merupakan implikasi penting dari perintah ini. ${ }^{10}$

Obligasi [kewajiban] untuk menguburkan kerabat yang meninggal, pertama kali terindikasi dalam narasi mengenai permintaan Abraham untuk mendapatkan sebuah tempat penguburan yang layak bagi istrinya, Sara (Kej. 23:3dst). Selanjutnya, bagi orang-orang Yahudi, penguburan yang layak bagi kerabat yang sudah meninggal harus diprioritasikan melampaui: studi terhadap Taurat, melayani di Bait Suci, menyiapkan kurban Paskah, melaksanakan sunat, dan membaca Megillah (Megillah 3b). ${ }^{11}$ Semua bentuk pelayanan penting ini, katakanlah demikian, harus ditangguhkan sementara demi pengurusan yang layak untuk menguburkan kerabat yang sudah meninggal. Itulah sebabnya, respons Yesus yang terkesan menyepelekan penanganan yang layak terhadap seorang ayah

${ }^{9}$ Crossley, The New Testament and the Jewish Law: A Guide for the Perplexed, 90.

${ }_{10}$ Craig S. Keener, A Commentary on the Gospel of Matthew (Grand Rapids, Michigan: Eerdmans, 1999), 276.

11 Keener menyebutkan bahwa beberapa Rabbi mengajarkan bahwa hormat kepada seorang guru lebih tinggi dari hormat kepada orangtua. Mereka mengajarkan demikian untuk menekankan mengenai pentingnya mempelajari Taurat Tuhan. Meski demikian, tidak seorang Rabbi pun yang mengajarkan bahwa mereka boleh menempatkan urgensi mempelajari Taurat melampaui penguburan yang layak terhadap orangtua yang meninggal (A Commentary on the Gospel of Matthew, 276-277). yang meninggal, merupakan sebuah tindakan yang dianggap sebagai skandal besar dalam lingkungan Yudaisme saat itu. ${ }^{12}$ Respons Yesus tersebut tentu sangat mengagetkan karena bahkan dalam Kitab Imamat, seorang imam dilarang untuk "menajiskan diri orang mati di antara orang-orang sebangsanya, kecuali kalau yang mati itu adalah...ibunya, ayahnya..." (21:1-2; huruf miring dari saya). Kewajiban untuk mengurusi penguburan orangtua yang meninggal dikemukakan juga dalam Misnah Berakot 3:1 sebagai sebuah kewajiban yang melampaui kewajiban untuk mengucapkan Shema dan mengenakan pakaian perkabungan. Dalam Kitab Tobit, dikisahkan bahwa Tobias menolak dinikahkan dengan seorang janda yang telah ditinggal mati oleh tujuh orang mendiang suaminya. Tobias khawatir bahwa ia sendiri akan ikut dibunuh oleh roh-roh jahat penjaga wanita itu. Bila itu terjadi, maka orangtuanya tidak lagi memiliki seorang putra untuk mengurusi penguburan mereka (6:13-15). ${ }^{13}$ Kisah Tobias ini disebutkan juga oleh Sanders yang berkomentar bahwa prinsip di balik kisah ini adalah "kewajiban untuk menguburkan orangtua merupakan dasar untuk membatalkan sebuah pertunangan."

Menurut tradisi Yahudi, seseorang yang meninggal mesti dikuburkan dalam jangka waktu 24 jam, bahkan bisa dilaksanakan kurang dari 6 jam setelah ia meninggal (Sirakh 22:12; Yudith 16:24; b. Sanh. 47b). ${ }^{15}$ Putra-putra dari orangtua yang meninggal itu harus memastikan sebuah penanganan yang layak bagi orangtuanya yang meninggal (Kej. 50:5; Tobit 4:3) mulai dari menyiapkan kuburan, ritual-ritual, dan konsisten dengan

${ }^{12}$ Infromasi di atas, disadur dari: Leon Morris, Luke (TNTC; Surabaya: Momentum, 2007), 197.

${ }^{13}$ Didasarkan atas terjemahan bahasa Inggris yang dikerjakan oleh: R.H. Charles, The Apocrypha and Pseudopigrapha of the Old Testament in English: Vol. I - Apocrypha (Oxford: Clarendon Press, 1913), 219.

${ }^{14}$ Sanders, Jesus and Judaism, 253.

${ }^{15}$ Lih. France, The Gospel of Matthew, 329; J.J. de Heer, Injil Matius Pasal 1-22 (Jakarta: BPK Gunung Mulia, 2003), 145; Craig S. Keener, The Gospel of Matthew: A Socio-Rhetorical Commentary (Grand Rapids, Michigan: Eerdmans, 2009), 275. 
aturan-aturan mengenai masa perkabungan. ${ }^{16}$ William Barclay menulis, "Bagi orang Yahudi, merupakan sebuah tugas yang suci untuk memastikan penguburan yang selayaknya bagi orangtua yang meninggal.,"17 Setelah penguburan selesai dilakukan, mereka akan memasuki masa perkabungan selama tujuh hari dan dalam masa ini kerabat terdekatnya tidak akan meninggalkan rumah kecuali pergi ke kuburan orangtua atau kerabat yang meninggal tersebut. Masa tujuh hari perkabungan ini diwarnai dengan kedatangan para kerabat yang lain atau tetangga yang berkunjung untuk menyatakan turut berdukacita serta memberikan penghiburan. Setelah melewati masa perkabungan pertama ini, kunjungan para kerabat berangsur sepi, namun kerabat terdekat dari orang yang meninggal itu akan meneruskan masa perkabungan berikutnya hingga genap tiga puluh hari, bahkan terus dilanjutkan hingga genap satu tahun. ${ }^{18}$

Craig S. Keener menyatakan bahwa baik dalam lingkungan Yahudi maupun lingkungan Greco-Roman, yang paling bertanggung jawab untuk mengurusi segala sesuatu berkenaan dengan penguburan seorang ayah/ibu adalah putra sulungnya. ${ }^{19}$

${ }^{16}$ Lih. France, Matthew, 160. Kej. 50:5, "bahwa ayahku telah menyuruh aku bersumpah, katanya: Tidak lama lagi aku akan mati; dalam kuburku yang telah kugali di tanah Kanaan, di situlah kaukuburkan aku. Oleh sebab itu, izinkanlah aku pergi ke sana, supaya aku menguburkan ayahku; kemudian aku akan kembali." Tobit 4:3, "Dan ia memanggil Tobias anaknya dan datang kepadanya dan dia berkata kepadanya, Kuburkan aku secara layak, dan hormatilah ibumu". Terjemahan saya terhadap Tobit 4:3 didasarkan atas terjemahan bahasa Inggris yang dikerjakan oleh: Charles, The Apocrypha and Pseudopigrapha of the Old Testament in English: Vol. I - Apocrypha, 211.

17 William Barclay, The Daily Study of the Bible: The Gospel of Matthew Volume 1 - Chapter 110 (Philadelphia: The Westminster Press, 1958), 320.

${ }^{18}$ Lih. B. R. McCane, "Burial Practice, Jewish," in Dictionary of New Testament Background, eds. Craig A. Evans and Stanley E. Porter (Software Version; Downers Grove, Illinois: InterVarsity Press, 2000).

${ }^{19}$ Craig S. Keener, The IVP Bible Background Commentary: New Testament (Downers Grove, Illinois: InterVarsity Press, 1993), 68.
Lebih luas lagi, "kewajiban umum untuk mengurusi orang yang meninggal sangat kuat"20 dalam lingkungan Yahudi, sekalipun orang yang meninggal itu bukan kerabat. Mereka menganggap bahwa tindakan mengurus dan menguburkan orang mati itu sendiri merupakan ekspresi kebaikan yang penuh kasih dan bahkan mengimitasi Tuhan sendiri yang "menguburkan Musa". ${ }^{21}$ Dunia Greco-Roman pun pada umumnya mewajibkan penanganan yang layak bagi orang-orang yang sudah meninggal. Martin Hengel menyatakan bahwa dalam dunia Greco-Roman, penolakkan untuk menguburkan seseorang biasanya dianggap sebagai suatu tindakan yang bengis bahkan untuk para kriminal sekalipun. $^{22}$

Jadi, permintaan untuk menguburkan ayah yang meninggal itu, merupakan sebuah permintaan yang bukan hanya masuk akal secara kultural, melainkan juga esensial secara teologis. Tidak heran, Adolf Schlatter mengomentari respons Yesus, "biarlah orang mati menguburkan orang mati mereka", sebagai "sebuah tindakan pelanggaran yang sangat jelas kesemberonoannya". ${ }^{23}$ Kaufmann Kohler menyebutnya sebagai sebuah respons yang "kejam dan tidak berperasaan" konteks jaman itu. Kita dapat memahami reaksi-reaksi semacam ini karena sebenarnya Yosefus sendiri pernah mengecam orangorang Zelot yang menolak menguburkan orang-orang yang terbunuh dalam peristiwa pemberontakan melawan Romawi. Mayatmayat itu dibiarkan tergeletak kaku di bawah terik matahari dan membusuk di jalanan. Yosefus mengecam tindakan mereka sebagai

${ }^{20}$ Sanders, Jesus and Judaism, 253.

21 Lih. beragama teks dari literartur-literatur Rabbinik yang dikutip untuk mendukung gagasan di atas, dalam: Davies and Allison, A Critical and Exegetical Commentary on the Gospel according to St. Matthew: A Commentary on Matthew 8-18, 53.

${ }^{22}$ Dikutip dalam: Sanders, Jesus and Judaism, 398. 252

23 Dikutip dalam: Sanders, Jesus and Judaism,

${ }^{24}$ Kaufmann Kohler, The Origins of Synagogue and the Church (New York: The Macmillan Company, 1929), 212. 
"barbarity" [kebiadaban]. ${ }^{25}$ Dalam parafrase yang lebih lembut, atas dasar latar belakang di atas, respons Yesus itu akan terdengar sangat ofensif bagi orang-orang Yahudi pada saat itu. Sepertinya respons ini meremehkan suatu tindakan yang mengekspresikan perhatian yang penuh kasih dan meninggalkan kesan yang membingungkan bagi mereka. ${ }^{26}$ Selain itu, pada satu kesempatan lain, Yesus sendiri pun mengkritik orang-orang Yahudi yang tampaknya sengaja mencari-cari alasan untuk mengabaikan pemeliharaan terhadap orangtua mereka (Mrk. 7:9-13). Mengapa sekarang Ia justru memberikan respons yang demikian?

Informasi-informasi di atas, tentunya sangat menarik dan menstimulasi kita untuk meneropong apa dan bagaimana para penafsir menjelaskan Matius 8:21-22/Lukas 9:59-60 yang dalam tulisan: Walter C. Kaiser, Jr., dkk., terkategori sebagai salah satu dari ucapan-ucapan yang sulit dalam Alkitab. ${ }^{27}$

25 Flavius Josephus, Josephus: The Complete Works, 1368 [The Jewish War VI. 3]. Ada sarjana yang meragukan faktualitas isi tulisan Yosefus. Meski demikian, entah faktual atau tidak, kecaman Yosefus tersebut merupakan kecaman yang wajar karena memang pada waktu itu, menolak untuk menguburkan orang yang sudah meninggal merupakan tindakan yang terkategori sebagai barbarity. Bnd. Stephen C. Barton, "The Relativisation of Family Ties in the Jewish and Graeco-Roman Traditions," in Constructing Early Christian Family: Family as Social Reality and Metaphor, ed. Halvor Moxnes (London: Routledge, 1997), 92. Di dalam Alkitab, kita mendapati beragam lontaran bernada ancaman bagi mereka yang memberontak terhadap Tuhan bahwa mayat mereka tidak akan dikuburkan tetapi akan dimakan oleh binatang-binatang buas dan membusuk di bawah terik matahari. Kecaman judgmental ini hanya bisa menakutkan bagi suatu masyarakat yang mengasumsikan penguburan yang layak sebagai suatu kehormatan (Ul. 28:26; Yer. 7:33; 8:1-2; Yeh. 6:5; 29:5; 39:17; Why. 11:9; bnd. Mzm. Salomo 4:19).

26 Lih. Davies and Allison, A Critical and Exegetical Commentary on the Gospel according to St. Matthew: A Commentary on Matthew 8-18, 55.

27 Lih. Walter C. Kaiser, Jr., et al, The Hard Sayings of the Bible (One-volume edition; Downers Grove, Illinois: InterVarsity Press, 1996) - [saya mendapatkan soft copy buku ini diinternet yang tidak mencantumkan nomor halaman]; juga dalam Gleason L. Archer, Jr., Encyclopedia of Bible Difficulties (Grand Rapids, Michigan: Zondervan, 1982), 324.

\section{SEJARAH EKSEGESIS: BERAGAM PANDANGAN}

Ulasan pada bagian ini akan dibagi ke dalam dua bagian besar yaitu, investigasi terhadap pandangan-pandangan mengenai alasan sang murid: "izinkan aku pulang dahulu menguburkan ayahku" dan respons Yesus: "biarlah orang mati menguburkan orang mati mereka".

\section{Alasan Sang Murid}

Setelah melakukan riset dengan membaca dan menganalisis beragam tafsiran mengenai alasan yang dikemukakan sang murid tersebut, saya mengelompokkan tafsiran-tafsiran tersebut ke dalam dua kategori, yaitu: pandangan bahwa ayah dari sang murid yang mengajukan alasan penundaan mengikut Yesus itu sudah meninggal dan sebaliknya pandangan bahwa ayahnya belum meninggal. Sebenarnya, pandangan bahwa ayah sang murid itu sudah meninggal dapat dirinci lagi menjadi dua variasi pandangan, yaitu pandangan bahwa ayah sang murid itu baru saja meninggal dan pandangan bahwa ayahnya sudah meninggal pada jangka waktu yang sudah cukup lama. Di sini, saya hanya akan mengulas pandangan bahwa ayah sang murid itu belum meninggal dan variasi pertama dari pandangan bahwa ayah sang murid itu sudah meninggal [baru saja meninggal]. Variasi kedua dari pandangan ini akan diulas pada bagian akhir artikel ini sebagai representasi dari pandangan yang saya anut.

\section{Ayahnya Belum Meninggal}

Banyak penafsir beranggapan bahwa alasan yang dikemukakan sang murid itu untuk "pergi dahulu menguburkan ayahku" sebenarnya tidak berarti bahwa ayahnya benar-benar telah meninggal saat itu. Di sini, saya hanya akan mengulas komentar dari William Barclay dan J.J. de Heer sebagai representasinya. $^{28}$

${ }^{28}$ Para penafsir lain yang menganut pandangan ini, antara lain: Kenneth E. Bailey, Through Peasant Eyes (Grand Rapids, Michigan: Eerdmans, 1980), 2627; Dunn, Christianity in the Making Volume 1: Jesus Remembered, 504; France, Matthew, 160; Matthew 
Barclay menyatakan bahwa bila ayah dari sang murid itu benar-benar telah meninggal, maka respons Yesus mestinya terdengar sangat keras dan tidak simpatik bagi orang-orang Yahudi. Itulah sebabnya, menurut Barclay kita seharusnya memberikan penjelasan alternatif ketimbang mengasumsikan bahwa orang tua sang murid itu benar-benar telah meninggal. Ia mengisahkan pengalaman seorang misionaris asal Siria yang melayani di Turki. Sang misionaris pernah menasihati seorang anak muda yang kaya untuk pergi ke Eropa dan melanjutkan studinya. Anak muda itu menjawab bahwa ia harus menguburkan ayahnya terlebih dahulu. Misionaris itu pun bersimpati dan menyatakan turut berbela sungkawa. Namun, pemuda itu menjelaskan bahwa maksudnya adalah ayahnya masih hidup dan ia harus merawatnya hingga ia meninggal. Bagi Barclay, inilah "penjelasan yang sebenarnya" terhadap kata-kata sang murid tatkala ia meminta ijin untuk menguburkan ayahnya terlebih dahulu. Ayahnya masih hidup, dan ia harus memenuhi kewajibannya untuk memelihara dan menjaga ayahnya hingga meninggal. Dan setelah itu, ia baru akan mengikuti Yesus. $^{29}$

J.J. de Heer mengikuti tafsiran Barclay di atas dengan mengemukakan alasan bahwa bila ayah sang murid itu benar-benar meninggal, maka ia tidak akan berlama-lama berada di tengah-tengah keramaian dan membuang waktu dengan meminta pendapat Yesus untuk mendapatkan ijin. de Heer merujuk juga kepada dugaan Alfred Plummer bahwa bisa jadi ayah sang murid itu sudah tua dan tidak lama lagi akan meninggal. ${ }^{30}$ Itulah

Henry, Injil Matius 1-14, terj. Lanny Murtihardjana, dkk (Surabaya: Momentum, 2007), 368; Archer, Encyclopedia of Bible Difficulties, 324.

${ }_{29}$ Barclay, The Daily Study of the Bible: The Gospel of Matthew Volume 1-Chapter 1-10, 320-321; juga William Barclay, The New Daily Study Bible: The Gospel of Luke (Revised and updated; Edinburgh: St. Andrew Press, 2001), 156-157.

${ }^{30}$ Tafsiran ini sebenarnya sudah dikemukakan juga oleh Yohanes Calvin yang menyatakan bahwa ayah sang murid itu sudah tua. Calvin memparafrasekan "ijinkan aku pergi dahulu menguburkan ayahku" sebagai "tidak ada banyak waktu yang tersisa" buat ayahnya (lih. A Harmony of the Gospels: Matthew, Mark and Luke, Vol. I, trans. A.W. Morrison, sebabnya murid itu meminta ijin terlebih dahulu karena ia menyangka bahwa penundaannya mengikuti Yesus tidak akan memakan waktu lama. ${ }^{31}$

Intinya, "Alasan ini dipakai untuk menunda mengikuti Kristus dengan segera", 32 karena ia mesti memenuhi kewajiban untuk memelihara ayahnya yang masih hidup itu hingga meninggal.

\section{Ayahnya Baru Saja Meninggal}

Pandangan bahwa ayah sang murid tersebut baru saja meninggal, dikemukakan oleh Sanders. Menurut Sanders, alasan sang murid untuk menguburkan sang ayah yang meninggal, merupakan alasan yang faktual. Pembacaan yang realistik terhadap narasi ini mengindikasikan bahwa "ayah pria itu benarbenar meninggal, dan Yesus benar-benar memanggil pria itu untuk mengikuti Dia ketimbang mengurus penguburan ayahnya."33 Empat belas tahun sebelum Sanders mengemukakan pandangan ini, Joachim Jeremias telah menyatakan bahwa ayah sang murid itu telah meninggal dan ia meminta ijin bukan hanya untuk mengurusi pemakamannya, melainkan juga sebagaimana tradisi Yahudi, mengikuti acara perkabungan yang berlangsung kurang lebih satu minggu sesudah pemakaman dilangsungkan. Respons Yesus yang bernada penolakkan itu bukan ditujukkan kepada tanggung jawab sang anak untuk menguburkan ayahnya secara layak, namun lebih ditujukan kepada lamanya tenggang waktu yang dibutuhkan untuk masa perkabungan itu. ${ }^{34}$ Morris melihat bahwa nada

eds. David W. Torrance and Thomas F. Torrance [Calvin's New Testament Commentaries; reprinted edition; Grand Rapids, Michigan: Eerdmans, 1989], 254-255).

${ }^{31}$ de Heer, Injil Matius Pasal 1-22, 145-146.

${ }^{32}$ Henry, Injil Matius 1-14, 368.

33 Sanders, Jesus and Judaism, 254. Di sini, Sanders mengikuti pandangan Hengel, The Charismatic Leader and His Followers, 3-15.

${ }^{34}$ Joachim Jeremias, New Testament Theology Vol. 1: The Proclamation of Jesus (London: SCM Press, 1971), 132. Pandangan di atas tampaknya sesuai dengan alur naratif Matius di mana setelah pengisahan narasi ini, Yesus dan para murid-Nya segera berlayar (8:23-27). Bila dihubungkan dengan pandangan Jeremias, Yesus memang tidak dapat menunggu selama 
urgensif dari panggilan menjadi murid dalam narasi ini hanya bisa memberikan efek dramatis yang lebih besar bila di balik permintaan ijin sang murid itu memang terdapat faktualitas meninggalnya sang ayah. $^{35}$

David L. Turner menolak pandangan bahwa ayah sang murid itu masih hidup, termasuk juga menolak bahwa permintaan ijin sang murid itu mengasumsikan tradisi penguburan ulang [second burial]. Menurutnya, pandangan-pandangan ini dapat mengalihkan perhatian kita dari ketatnya respons Yesus. ${ }^{36}$ Tidak jelas mengapa Turner menganggap pandangan-pandangan ini tidak memadai untuk dianut. Turner juga tidak mengemukakan posisinya secara eksplisit. Namun dari komentar lanjutannya, saya berkesimpulan bahwa bagi Turner, alasan sang murid bahwa ayahnya meninggal dan perlu diurusi terlebih dahulu memang sesuatu yang faktual. Turner, setelah menyinggung mengenai tanggung jawab seorang anak untuk mengurusi pemakaman ayahnya secara layak, menulis bahwa alasan itu sah menurut Taurat. Namun, reaksi Yesus yang tajam itu memperlihatkan bahwa Kerajaan Allah harus lebih utama dibandingkan dengan sikap seseorang terhadap keluarganya (bnd. Mat. 10:37; 12:46-50). ${ }^{37}$ Sampai di sini, kita mendapati bahwa Turner hanya bisa memberi efek "lebih" kepada tuntutan Yesus akan sikap terhadap Kerajaan Allah dalam komentarnya, bila ia memang mengasumsikan faktualitas kematian ayah sang murid tersebut. Artinya, sang murid itu harus menentukan pilihan: mengurusi ayahnya yang meninggal itu, atau mengikuti Yesus saat itu juga! ${ }^{38}$

itu karena Ia menginginkan murid tersebut ikut bersama-Nya di atas perahu itu. Kontras terhadap pertimbangan ini, lih. France, The Gospel of Matthew, 326, yang menyatakan bahwa tanggapan Yesus terhadap sang murid itu bukan fokus pada pelayaran dengan perahu yang akan segera dilakukan, melainkan gaya hidup berpindah-pindah yang harus dilakoni para murid pada waktu itu.

${ }^{35}$ Morris, Luke, 197.

36 David L. Turner, Matthew (BECNT; Grand Rapids, Michigan: Baker Academic, 2008), 239-240.

${ }^{37}$ Lih. Turner, Matthew, 240.

${ }^{38}$ Kaiser, et al, juga tidak menyatakan posisi mereka secara eksplisit. Namun, tulisan singkat mereka

\section{RESPONS YESUS}

Di sini, saya akan mengelompokkan pandangan para penafsir terhadap respons Yesus, dalam empat kategori.

\section{Metafora mengenai Orang-orang Non Percaya}

Tulisan dari beberapa Bapak Gereja yang saya temui, pada umumnya tidak memberi perhatian terhadap alasan sang murid untuk menguburkan ayahnya terlebih dahulu. Mereka lebih tertarik untuk menjelaskan tentang maksud respons Yesus: "biarlah orang-orang mati menguburkan orang-orang mati mereka". 39

Bagi Klemens dari Aleksandria (Abad II), "orang-orang mati" yang dimaksudkan Yesus di sini adalah sebuah metafora yang paralel dengan kecaman Paulus terhadap kaum Epikurean yang bersemboyan: "Mari kita makan dan minum sebab besok kita mati" (1Kor. 15:32). Orang-orang ini bisa jadi

mengenai bagian ini diakhiri dengan kesaksian dari John McNeil yang mendapatkan kabar mengenai kematian ayahnya saat sedang mempersiapkan diri untuk berkhotbah. McNeil memilih untuk tetap berkhotbah ketimbang segera pulang karena merasa bahwa bagian ini cocok dengan situasinya. Tentu saja, kesaksian yang dikemukakan Kaiser dkk, ini mengindikasikan bahwa mereka menganut pandangan bahwa ayah sang murid itu baru saja meninggal dan ia harus memilih: pulang mengurusi pemakaman ayahnya atau mengikuti Yesus saat itu juga (lih. Hard Sayings of the Bible - tanpa no. hlm; lih. catatan kaki no. 28).

39 Saya mendapatkan petunjuk mengenai tafsiran Bapak-bapak Gereja yang saya ulas di sini dari sebuah artikel yang ditulis oleh: Herbert W. Basser, "Let the Dead Bury Their Dead: Rhetorical Features of Rabbinic and New Testament Literature," in Approaches to Ancient Judaism, eds. Herbert W. Basser and S. Fishbane (New Series, Vol. 5; Atlanta: Scholar Press, 1989), 79-96. Artikel ini dipublikasikan juga secara online, di: ftp://ftp.lehigh.edu/pub/listserv/ ioudaios-l/Articles/hbbury, diakses tanggal 8 Maret 2013. Saya membaca dan mengutip tulisan Basser ini dari versi online-nya. Meski demikian, saya mencari sumber-sumber yang dirujuk Basser kemudian mengulasnya kembali di sini. Jadi untuk ulasan pada bagian ini, saya berhutang kepada Basser namun saya memang membaca kembali tulisan-tulisan Bapakbapak Gereja yang dirujuk Basser. Itulah sebabnya, untuk rujukan sumber, saya mengacu kepada tulisan dari Bapak-bapak Gereja tersebut di mana sumbersumber yang saya rujuk kadang berbeda nomor halamannya dari yang dirujuk Basser. 
berada dalam Gereja dengan penampilan luar yang saleh, namun sebenarnya mereka tidak lebih dari pada orang-orang yang bertopeng. Dengan hidup secara demikian, mereka sedang menenggelamkan diri mereka sendiri ke dalam kematian. Mereka sedang berada dalam proses menuju kematian, yaitu terpisah dari Allah, yang ditandai dengan "penguburan" yaitu tindakan memisahkan diri dari Allah. ${ }^{40}$ Siprianus (Abad III) memahami respons Yesus sebagai sebuah metafora berdasarkan konsep kontras antara "ayah yang mati" dan "Allah sebagai Bapa yang hidup". Tafsiran metaforik ini dibangun atas alusi kepada Doa Bapa Kami di mana Allah disebut sebagai "Bapa". Bapa yang di sorga itu adalah Bapa yang hidup, sementara sang murid itu hendak pergi mengurusi "bapaknya yang mati". Respons Yesus bukan merupakan larangan untuk menunaikan Taurat [tanggung jawab mengurusi orangtua yang meninggal], melainkan sebuah metafora yang menekankan bahwa hanya orang-orang yang mati secara spirituallah yang memiliki bapak yang mati, dan hanya orang-orang yang hidup secara spirituallah yang memiliki Bapa yang hidup. ${ }^{41}$ Yohanes Krisostomus (Abad IV-V) menafsirkan "orang mati menguburkan orang mati" sebagai metafora bagi orang-orang non percaya. Orang-orang non percaya itulah yang akan menguburkan ayah sang murid yang meninggal. Kelihatannya Krisostmus percaya bahwa alasan kematian sang ayah yang dikemukakan murid itu memang faktual. Ia menyatakan bahwa Yesus tidak memaksudkan bahwa ayah sang murid itu dibiarkan tidak terkubur karena orang-orang non percaya ["orang-orang mati"] yang akan mengu-burkannya. Krisostomus menulis, "Jika engkau kagum kepada anak muda itu, karena ia datang menemui Yesus dan tidak

\footnotetext{
${ }^{40}$ Clemens of Alexandria, "The Instructor Book III, Chapter X," in The Ante-Nicene Fathers Vol. 2, trans. Philip Schaff, eds. Alexander Roberts and James Donaldson (Grand Rapids, Michigan: Christian Classics Ethereal Library, 1819-1893), 620.

${ }^{41}$ Cyprian, "The Treatises of Cyprian: 'On the Lord's Prayer', Treatise IV.9," in Ante-Nicene Fathers Vol. 5, ed. Philip Scaff, trans. Ernest Wallis (Grand Rapids, Michigan: Christian Ethereal Classics Library, 1819-1893), 1046.
}

pergi atas kehendaknya sendiri, lebih lagi engkau seharusnya kagum bila ia tetap tinggal saat dilarang pergi". ${ }^{42}$ Agustinus (Abad IVV), ketika menulis surat kepada Evodius, menafsirkan respons Yesus tersebut sebagai sebuah metafora bagi orang-orang non percaya yang mati secara spiritual. Mereka mati secara spiritual karena mereka belum menerima anugerah Allah. ${ }^{43}$

Selanjutnya, pada era Reformasi, pemahaman metaforis terhadap respons Yesus kepada murid tersebut juga dominan. Matin Luther, seperti umumnya tafsiran Bapakbapak Gereja di atas, memahami respons Yesus sebagai metafora, namun secara spesifik ia kaitkan dengan orang-orang yang melanggar dan mencemari sakramen dan Injil. Ia juga menautkan metafora "orang-orang mati" itu kepada Paus. ${ }^{44}$ Calvin pun memahami respons tersebut sebagai metafora, namun berbeda dengan Luther, ia memahaminya secara umum yaitu bagi mereka yang hidup secara sia-sia dan tidak berguna tanpa Allah. ${ }^{45}$ Bagi Calvin, Yesus tidak bermaksud melarangnya untuk mengurusi pemakaman ayah murid itu. Dalam tafsirannya terhadap Lukas 9:60, Calvin menyatakan bahwa maksud Yesus adalah

42 John Chrysostom, "Homilies of St. John Chrysostom on the Gospel of St. Matthew: Homily XXVII," in Nicene and Post-Nicene Fathers, Series I, Vol. 10, ed. Philip Scaff, trans. Sir George Prevort Barones, revised by M.B. Riddle (Grand Rapids, Michigan/Edinburgh: Eerdmans/T. \& T. Clark, 1888), 333.

43 Augustine, "Letters of St. Augustine: To Evodius Ch. VI.21 [414 AD]," in Nicene and PostNicene Fathers Series I, Vol. 1, ed. Philip Scaff, trans. J.G. Gunningham (Grand Rapids, Michigan/Edinburgh: Eerdmans/T. \& T. Clark, 1886), 1116. Agustinus merujuk kepada respons Yesus terhadap permintaan sang murid itu beberapa kali dalam tulisan-tulisannya yang berbeda dengan gagasan metaforik yang sama seperti yang sudah dicantumkan di atas. Lih. Basser, "Let the Dead Bury Their Dead: Rhetorical Features of Rabbinic and New Testament Literature".

44 Seperti yang diulas oleh: Basser, "Let the Dead Bury Their Dead: Rhetorical Features of Rabbinic and New Testament Literature".

${ }^{45}$ Calvin, A Harmony of the Gospels: Matthew, Mark and Luke, 255. 
bahwa murid itu harus fokus kepada panggilan untuk memberitakan Injil. ${ }^{46}$

Para penafsir modern yang menganut tafsiran bahwa sebenarnya ayah dari sang murid itu masih hidup, biasanya memahami respons Yesus tersebut juga dalam pengertian metaforik, yaitu "biarlah orang yang mati secara rohani menguburkan orang mati". Menurut mereka, Yesus mengasumsikan bahwa orang-orang yang bukan pengikut-Nya sedang hidup dalam "masyarakat yang mati secara rohani" [death society], dan itulah sebabnya Ia memanggil sang murid itu untuk meninggalkan komunitas itu sesegera mungkin. ${ }^{47}$ France tampaknya condong kepada usulan bahwa ayah sang murid itu belum meninggal dan menganggap bahwa respons Yesus itu merupakan sebuah metafora (bnd. Mat. 10:39; 16:25-26; Ef. 2:1, 5; Kol. 2:13; Why. 3:1) yang dalam taraf tertentu menuntut fanatisme yang melampaui sikap terhadap berbagai tuntutan kehidupan sosial. Sikap fanatisme seperti inilah yang dapat menjelaskan mengapa Yesus pada kesempatan lain berkata bahwa banyak yang dipanggil namun sedikit yang dipilih (Mat. 20:16; $22: 14$; bnd. $7: 14){ }^{48}$

Ada pula penafsir kontemporer yang tidak memberikan keputusan mengenai faktual atau tidaknya kematian ayah sang murid, namun lebih memberi perhatian terhadap maksud dari respons Yesus. Davies dan Allison juga menyetujui bahwa respons Yesus mesti dipahami dalam pengertian di atas karena tidak mungkin kita memahami kata-kata Yesus secara literal seakan-akan orang mati dapat melakukan sesuatu bagi orang mati yang lain. ${ }^{49}$ Demikian pula Kohler menyatakan bahwa maksud dari respons Yesus adalah biarkanlah orang-orang di kota tersebut yang adalah "masyarakat pekuburan"

\footnotetext{
${ }^{46}$ Calvin, A Harmony of the Gospels: Matthew, Mark and Luke, 255.

${ }^{47}$ Barclay, The Daily Study of the Bible: The Gospel of Matthew Volume 1-Chapter 1-10, 321-322; de Heer, Injil Matius Pasal 1-22, 146; Henry, Injil Matius 1-14, 368-370.

${ }^{48}$ France, The Gospel of Matthew, 330-331.

${ }^{49}$ Davies and Allison, A Critical and Exegetical Commentary on the Gospel according to St. Matthew: A Commentary on Matthew 8-18, 56.
}

[dalam arti mati secara rohani] yang mengurus pemakaman itu. ${ }^{50}$ Yesus tidak menolak penanganan terhadap sang ayah, melainkan Ia mengalihkan tanggung jawab itu dari sang murid tersebut kepada pihak lain.

Ringkasnya, mereka yang memahami respons Yesus secara metaforik, tidak memahaminya sebagai sebuah larangan bagi sang murid itu untuk menunaikan kewajiban terhadap orangtuanya. Penekanan dari respons Yesus adalah agar sang murid melihat panggilan itu sebagai sebuah urgensi yang tidak boleh ditunda. Mereka fokus kepada aspek positif dari respons itu, yaitu panggilan untuk memenuhi kewajibannya sebagai "murid", yaitu mengikuti Yesus sesegera mungkin.

\section{Resistensi terhadap Taurat}

Para penafsir lain melihat respons Yesus sebagai sebuah ekspresi perlawanan yang sangat tegas terhadap validitas Taurat. Ada yang memang tidak menganggapnya sebagai sebuah resistensi mutlak, namun dalam taraf tertentu respons Yesus menandai diskontinuitas [ketidaksinambungan] antara panggilan-Nya dan tuntutan Taurat. Dalam korpus pemahaman ini, tidak hanya aspek positif dari respons Yesus sebagaimana yang sudah diulas di atas, tetapi aspek negatifnya mendapat perhatian lebih. Secara umum, para penafsir yang pandangannya akan diulas berikut ini, memahami respons Yesus sebagai sebuah penolakkan terhadap Taurat, tentunya dalam tingkat atau variasi yang beragam.

Donald A. Hagner mendiskusikan mengenai kemungkinan bahwa alasan sang murid di atas berarti bahwa ayahnya belum meninggal dan ia mesti mengurusnya hingga meninggal. Hagner tidak menetapkan secara jelas pandangannya mengenai kemungkinan ini atau kemungkinan lainnya. Ia langsung berargumentasi bahwa kemungkinan ini pun mengasumsikan bahwa respons Yesus merupakan perlawanan terhadap kewajiban memelihara orangtua sebagai bagian dari perintah menghormati mereka. Hal mengikut Yesus melampaui tuntutan ketaatan terhadap

${ }^{50}$ Kohler, The Origins of Synagogue and the Church, 212; juga: Turner, Matthew, 240. 
segala sesuatu yang lain, termasuk Taurat. ${ }^{51}$ Sebagaimana yang dinyatakan juga oleh Hagner, pandangan ini telah dikemukakan sebelumnya oleh Sanders. Bagi Sanders, respons Yesus mengandung implikasi positif maupun negatif. Secara positif, respons Yesus memperlihatkan bahwa panggilan untuk menjadi seorang murid lebih urgen ketimbang kewajiban apa pun. Keputusan untuk memberikan diri sebagai alat kerajaan Allah tidak dapat ditunda untuk alasan apa pun. Namun, implikasi negatifnya harus diperhatikan secara lebih serius. Respons Yesus merupakan cerminan dari sikap-Nya yang secara sadar menyaratkan ketidaktaatan terhadap perintah yang dipahami oleh semua orang Yahudi sebagai perintah yang berasal dari Tuhan. Menurut Sanders, hal mengikuti Yesus lebih penting daripada ketaatan terhadap Taurat atau aturan-aturan kesalehan mana pun. ${ }^{52}$ Turner, di sisi lain, menyebut respons Yesus sebagai sebuah hiperbol, namun ia berkesimpulan tepat seperti yang dikemukakan Sanders. ${ }^{53}$

Markus Bockmuehl menulis sebuah artikel mengenai Matius 8:22/Lukas 9:60 yang di dalamnya terdapat tinjauan mengenai pandangan Sanders yang sebenarnya merupakan turunan dari pandangan yang sebelumnya sudah dikemukakan Hengel. Tinjauan Bockmuehl secara meyakinkan memperlihatkan bahwa karakteristik disjunktif antara Injil vs Taurat sangat dominan dalam pandangan Hengel dan Sanders terhadap respons Yesus. Seakan-akan, demikian tinjuan Bockmuehl, respons Yesus itu menghadirkan pilihan: taat kepada Injil [panggilan Yesus] atau taat kepada Taurat. Memutuskan untuk mengikut Yesus berarti mengabaikan penanganan yang layak terhadap penguburan sang ayah, dan itu sama dengan tidak menaati Taurat. Figur Yesus yang terekspresi dari responsnya dalam tafsiran Hengel dan Sanders, menurut analisis Bockmuehl, adalah figur seorang antinomian

${ }^{51}$ Donald A. Hagner, Matthew 1-13 (Software Version of WBC, Vol. 33a; Dallas, Texas: Word Books Publishers, 1998).

${ }^{52}$ Sanders, Jesus and Judaism, 253-255.

${ }^{53}$ Turner, Matthew, 240. [anti hukum]. Bockmuehl juga mendaftarkan nama-nama sarjana modern yang bersimpati terhadap pandangan Hengel dan Sanders, mis. Craig L. Blomberg, Joachim Gnilka, Ulrich Luz, F. Bovon, John Nolland, H. Schurmann, J.H. Charlesworth, H. Merkel, B.F. Meyer, N.T. Wright, dan Stephen C. Barton. Membaca analisisnya dan pencantuman begitu banyak nama sarjana kontemporer penganut pandangan ini, saya setuju dengan Bockmuehl bahwa pandangan inilah yang paling dominan dianut dan didiskusikan dalam tiga puluh tahun terakhir ini. Bockmuehl sendiri memilih pandangan alternatif yang lain ketimbang pandangan ini [akan diulas pada poin berikutnya]. ${ }^{54}$

Bockmuehl tidak menyebutkan nama Thomas R. Schriener, namun dalam pembacaan saya, pandangan Schreiner pun dapat dikategorikan dalam korpus pandangan ini. Schreiner memang tidak mengikuti persis pandangan Sanders [dan Hengel] yang sangat tajam mengenai sikap Yesus terhadap Taurat seperti yang sudah diulas di atas. Lebih lunak, Sanders berpandangan bahwa dalam PB, sikap Yesus terhadap Taurat dapat dipahami dalam dua kategori, yaitu kontinuitas dan diskontinuitas. Sikap kontinuitas terlihat dalam afirmasi Yesus terhadap validitas Taurat. Namun, Yesus juga bersikap kritis terhadap Taurat [dan tafsiran terhadap Taurat dalam tradisi Yahudi]. Sikap kritis inilah yang disebut Schreiner sebagai diskontinuitas. Dan ia menyebutkan respons Yesus terhadap murid tersebut dalam konteks sikap diskontinuitas-Nya terhadap Taurat. ${ }^{55}$

54 Markus Bockmuehl, "Let the Dead Bury Their Dead' (Matt. 8:22/Luke 9:60): Jesus and the Halakhah," in Journal of Theological Studies (1998): 553-581. Versi online dari artikel ini dipublikasikan di: http://www.accessmy library.com/article-1G121263299/let-dead-bury-their.html, diakses tanggal 7 Maret 2013. Saya membaca dan mengutip artikel Bockmuehl dari versi onlinenya.

55 Tulisan Schreiner adalah tulisan mengenai teologi PB. Itulah sebabnya, ia memperhatikan seluruh data PB mengenai Taurat. Lih. Thomas R. Schreiner, New Testament Theology: Magnifying God in Christ (Grand Rapids, Michigan: Baker Academic, 2008), 617-672. Dalam ulasannya mengenai Taurat dan sejarah keselamatan dalam PB, ia mengutip tulisan Sanders yang sudah saya kutip di atas di halaman 625 
Akhirnya, seperti yang sudah dikemukakan sebelumnya, Jeremias mengarahkan penolakkan Yesus bukan pada kewajibannya mengurusi jenasah ayah sang murid itu, namun waktu perkabungannya. Meski demikian, juga sebagaimana yang sudah dijelaskan sebelumnya, pandangan ini pun tidak dapat menghilangkan kesan perlawanan terhadap aturan-aturan mengenai perkabungan yang merupakan bagian dari sikap menghormati orangtua yang meninggal dan penanganan yang layak terhadapnya.

Dalam rubrik pemahaman ini, kata-kata kuncinya adalah resistensi (penolakkan) dan nulifikasi (pembatalan) terhadap validitas Taurat yang pertentangkan dengan panggilan Kerajaan Allah.

\section{Retroversi: Hipotesis Aramaik dan Ibrani}

Beberapa penafsir lain mencoba melembutkan kesan resistensif dari respons Yesus dengan memberikan usulan alternatif. Menurut mereka, respons Yesus "biarlah orang-orang mati menguburkan orang-orang mati mereka" tidak masuk akal dalam konteks jaman itu dan mungkin merupakan kesalahan penerjemahan dari bahasa Aramnya. Seperti yang kemukakan Basser, mereka yang menganut pendekatan ini menganggap bahwa pendekatan ini bermanfaat untuk menangani frasa-frasa problematis dalam teks Yunaninya. Kita tahu bahwa bahasa Aram dan Ibrani awalnya hanya terdiri atas konsonankonsonan dan biasanya ada sejumlah pilihan arti bergantung penempatan vokal-vokal pada kata-kata Aram/Ibraninya. Bisa jadi bahwa penerjemahan ke dalam bahasa Yunaninya menjadi "aneh" karena keputusan yang salah dari si penerjemah mengenai vokal-vokal apa yang harus digunakan pada teks Aramaiknya. Dengan melakukan rekonstruksi ini, kita tertolong untuk menerjemahkan ulang kesalahan penerjemahan yang terdapat dalam teks Yunaninya. ${ }^{56}$ Biasanya pendekatan ini mengasumsikan penerimaan akan hipotesis

catatan kaki no. 22, dan mendiskusikan mengenai Matius 8:21-22/Lukas 9:59-60 dalam halaman 626.

56 Basser, "Let the Dead Bury Their Dead: Rhetorical Features of Rabbinic and New Testament Literature" [versi online]. bahwa naskah asli Injil Matius ditulis dalam bahasa Aram kemudian baru diterjemahkan ke dalam bahasa Yunani, ${ }^{57}$ walau tidak harus demikian. ${ }^{58}$ Jadi yang harus dilakukan adalah menetapkan kembali teks Aramnya dan menafsirkan ulang respons Yesus tersebut dalam nuansa Aramaiknya atau yang biasanya disebut dengan istilah retroversi (retroversion).

Oleh karena ulasan detail untuk rekonstruksi retroversi ini sangat teknis, maka di sini saya hanya akan mendaftarkan variasivariasi penerjemahan ulang terhadap respons Yesus dalam Matius 8:22/Lukas 9:60 yang

57 Hipotesis di atas didasarkan atas tulisan Papias yang dikutip oleh Eusebius: "Matius menyusun perkataan-perkataan dalam bahasa Ibrani dan setiap orang menafsirkan semampu mereka" (Ecclesiastical History III.39.16, trans. C.F. Cruse [Peabody, Massachusetts: Hendrickson Publishers, 2004], 106). Bapak-bapak Gereja lain (mis. Irenaeus dan Origenes) juga menegaskan tulisan Papias. Tulisan Papias ini sebenarnya tidak jelas dalam beberapa bagian dan menimbulkan diskusi yang tidak konklusif hingga kini. Diskusi mengenai hal ini, dapat dibaca dalam: Donald Guthrie, Pengantar Perjanjian Baru Volume 1, terj. Hendry Ongkowidjojo (Surabaya: Momentum, 2010), 28-32; D.A. Carson, Douglas J. Moo, and Leon Morris, An Introduction to the New Testament (Grand Rapids, Michigan: Zondervan, 1992), 69-71; Scot McKnight, "Matthew, Gospel of," in Dictionary of Jesus and the Gospels, eds. Joel G. Green; Scto McKnight, and Ian Howard Marshall (Software Version; Downers Grove, Illinois: InterVarsity Press, 1998). Penerapan dari hipotesis ini terdapat dalam monograf yang ditulis oleh: Maurice C. Casey, An Aramaic Approach to Q: Source for the Gospels of Matthew and Luke (Society for New Testament Studies, Monograph Series 122; Cambridge: Cambridge University Press, 2002). Dalam monograf ini, Casey tidak menyinggung tentang retroversi terhadap Matius 8:22/Lukas 9:60.

${ }^{58}$ Mis. Robert M. Grant dan Joseph A. Fitzmyer mempertanyakan hipotesis bahwa naskah asli Injil Matius ditulis dalam bahasa Aram, namun tetap menerima rekonstruksi teks dengan melakukan retroversi. Kedua penulis ini percaya akan adanya ucapan-ucapan Yesus yang terkoleksi dalam bahasa Aram, walau tidak seluruh isi Injil Matius merupakan terjemahan dari bahasa Aram. Mereka pun melihat manfaat retroversi sebagaimana yang sudah dikemukakan di atas (lih. Joseph A. Fitzmyer, A Wandering Aramean: Collected Aramaic Essays (Society of Biblical Literatur, Monograph Series 25; Chico, California: Scholars Press, 1979), 14-15. 
pernah diusulkan berdasarkan hipotesis Aramaik, antara lain: ${ }^{59}$

a. "Biarlah orang-orang yang sudah mati menguburkan orang-orang matinya". 60

b. "Tinggalkan orang-orang mati bagi 'para penggali kubur'”.

c. "Biarlah orang-orang yang tidak mengambil keputusan menguburkan orang-orang mati mereka". ${ }^{6}$

d. "Biarlah orang-orang muda menguburkan orang-orang mati".

e. "Tinggalkanlah itu bagi orang-orang di kota itu".

f. "Penduduk kota itu akan menguburkan orang mati itu"62

Selain retroversi berdasarkan hipotesis Aramaik, ada juga retroversi berdasarkan hipotesis Ibrani. McDaniel yang menganut hipotesis ini, percaya bahwa Yesus berbicara kepada murid tersebut dalam bahasa Ibrani. Alasannya, seperti para Rabbi lainnya yang biasa mengajarkan para muridnya menggunakan bahasa Ibrani, demikian pula Yesus saat itu. ${ }^{63}$ Ia mendasarkan retroversinya atas teks Injil Matius versi Ibrani yang dikerjakan oleh Shem Tob Ibn Shaprut $( \pm$ thn. $1400 \mathrm{M}) .{ }^{64}$ Respons Yesus dalam Matius 8:22

${ }^{59}$ Daftar variasi terjemahan ulang di atas, saya kutip dari studi yang dilakukan oleh profesor Thomas F. McDaniel, Clarifying More Baffling Bilblical Passages (Narrberth, Pennsylvannia: n.p., 2008), 290291. Versi online dari buku McDaniel, khususnya bab yang membahas tentang Matius 8:22/Lukas 9:60, dapat diakses di: http://tmcdaniel. Palmerseminary.edu/CBBP_Chapter_29.pdf, diaskes tanggal 7 Maret 2013. Meski demikian, beberapa di antara usulan terjemahan ulang tersebut saya beri rujukan sumber sejauh yang bisa saya temui.

${ }^{60}$ Alan Hugh M'Neile, The Gospel according to St. Matthew (London: Macmillan, 1915), 110.

${ }^{61}$ Matthew Black, "Let the Dead Bury Their Dead," in The Expository Times 62 (1949-1950): 219220 .

62 Basser, "Let the Dead Bury Their Dead: Rhetorical Features of Rabbinic and New Testament Literature" [versi online].

${ }^{63}$ McDaniel, Clarifying More Baffling Bilblical Passages, 295.

${ }^{64}$ McDaniel, Clarifying More Baffling Bilblical Passages, 293. Injil Matius versi Ibrani tersebut pada umumnya diberi penanggalan pada Abad Pertengahan, versi Shem Tob, tertera demikian: לקבור מתיהם ועזוב המתים, yang menurut McDaniel memiliki empat kemungkinan arti, ${ }^{65}$ yaitu:

a. "Biarlah orang-orang itu menguburkan orang-orang mati mereka";

b. "Biarlah orang-orang mati menguburkan orang-orang mati mereka";

c. "Biarlah orang-orang yang sekarat itu menguburkan orang-orang mati mereka"; dan

d. "Biarlah para kerabat/saudara-saudara yang lain menguburkan orang-orang mati mereka"

McDaniel memilih opsi d karena bisa jadi Yesus mengasumsikan murid tersebut masih memiliki kerabat lain yang dapat mengurusi ayahnya yang sudah atau akan meninggal itu. $^{66}$

\section{Motif Nazir dan "Kerabat Fiktif"}

Pandangan alternatif ini dikonstruksi berdasarkan asumsi pandangan pada poin $\mathrm{b}$ di atas [resistensi terhadap Taurat], namun menyimpulkannya secara berbeda. Seperti pandangan $\mathrm{b}$, pandangan alternatif ini memahami respons Yesus berkait erat dengan validitas Taurat. Namun, tidak seperti pandangan $b$, pandangan alternatif ini memahami respons Yesus sebagai sebuah "kekecualian" yang berlatar belakang pada

walau ada pandangan minoritas yang memberi penanggalan yang lebih awal; lih. Dennis C. Duling, "The Gospel of Matthew," in The Blackwell Companion to the New Testament, ed. David E. Aune (West Sussex: Willey-Blackwell, 2010), 299.

${ }^{65}$ Ambiguitas arti di atas bukan disebabkan pada kata-kata Yesus. Kata-kata Yesus pasti jelas dipahami oleh mereka yang mendengarnya saat itu karena dalam penuturan oralnya, bunyi vokal yang digunakan jelas sekali menentukan artinya. Namun, ketika kata-kata Yesus itu dituangkan dalam bentuk tulisan, di mana bahasa Ibrani hanya menggunakan konsonan-konsonan, maka penerjemahannya ke dalam bahasa Yunani berhadapan dengan ambiguitas di atas, dan penerjemahnya memilih opsi b saat menerjemahkan kata-kata Yesus dari bahasa Ibrani ke dalam bahasa Yunani (McDaniel, Clarifying More Baffling Bilblical Passages, 295-296).

${ }^{66}$ McDaniel, Clarifying More Baffling Bilblical Passages, 295. 
aturan PL, yaitu aturan bagi orang yang bernazar untuk menjadi seorang nazir.

Dalam PL, seseorang yang telah bernazar untuk menjadi nazir, selain beberapa aturan lainnya, dilarang untuk menyentuh jenasah, termasuk jenasah kerabat terdekat mereka (Bil. 6:6-7). Hal yang sama juga berlaku bagi seorang imam besar (Im. 21:1011). Rupanya aturan ini terus dipelihara hingga pada masa Yesus. Dalam tulisan Filo yang hidup sejaman dengan Yesus, kita mendapati lontaran serupa mengenai larangan bagi seorang imam besar dan seorang nazir untuk mencemari dirinya dengan menyentuh jenasah, termasuk jenasah orangtuanya (tentang seorang imam besar, lih. Spec. Leg. 1.113-115; tentang seorang nazir, lih. Spec. Leg. 1.250). Meski demikian, para rabbi yang hidup lebih belakangan memberikan kekecualian bagi seorang imam besar dan seorang nazir untuk mengurusi jenasah dan mengupayakan penanganan yang layak baginya, khususnya bagi jenasah yang tidak terurus oleh pihak mana pun (m. Nazir 7.1).

Penafsir yang sudah disebutkan sebelumnya, Bockmuehl, percaya bahwa ketimbang memahami respons Yesus tersebut sebagai sebuah resistensi terhadap Taurat, lebih baik memahaminya sebagai respons yang menggemakan motif kenaziran. Bockmuehl menyadari bahwa proposal ini bersifat tentatif (tidak pasti) karena buktibukti yang mendukungnya sangat kabur. Namun ia yakin bahwa proposal ini jauh lebih memungkinkan untuk dianut. Di samping menyatakan bahwa pada masa Yesus (Yohanes Pembaptis adalah seorang nazir!) nazar untuk menjadi nazir sangat popular, Bockmuehl juga merujuk kepada serangkaian catatan para penulis Injil yang menggemakan motif ini secara sporadis dalam kehidupan Yesus, walau bukan dalam nuansa yang benar-benar konsisten dengan isi larangan bagi seorang nazir dalam PL. Misalnya, Yesus tidak menikah; tidak ada catatan bahwa Ia mencukur rambut-Nya; dan mendekati akhir
pelayanan-Nya, Yesus menyatakan bahwa Ia tidak akan minum anggur lagi. ${ }^{67}$

Pertanyaannya, jika motif kenaziran melumuri respons Yesus, bagaimana menghubungkannya dengan murid yang meminta ijin itu? Bukankah respons tersebut ditujukan kepadanya, bukan berkenaan dengan diri Yesus sendiri? Bockmuehl mengakhiri artikelnya dengan konklusi yang berisi singgungan mengenai motif keluarga dalam ajaran Yesus. Dalam beberapa bagian, Yesus sangat eksplisit menuntut sebuah komitmen yang radikal terhadap-Nya melampaui komitmen terhadap keluarga biologis (bnd. Mat. 10:37; bnd. 12:50; Mrk. $\left.3: 31-35 ;{ }^{68} 10: 28-31\right)$. Fakta bahwa Yesus tidak menikah dan radikalitas tuntutannya terhadap komitmen para murid terhadap-Nya, paralel dengan nazar seorang nazir untuk menempatkan Allah lebih daripada apa pun di dalam dunia ini. Tentu saja Yesus tidak mengabaikan tanggung jawab kekerabatan biologis (bnd. Mrk. 1:29-31; 7:8-13). Meski demikian, Ia membentuk keluarga yang baru yang terdiri atas para pengikut-Nya dan Ia memanggil mereka untuk memberikan komitmen tertinggi mereka terhadap komunitas yang baru ini melebih ikatan tanggung jawab kekerabatan biologis mereka. Jadi, respons Yesus tersebut dipahami Bockmuehl sebagai respons yang berkaitan

${ }^{67}$ Bockmuehl, “'Let the Dead Bury Their Dead' (Matt. 8:22/Luke 9:60): Jesus and the Halakhah" [versi online].

68 Dalam konteks pandangan mengenai komunitas kekerabatan yang baru tanpa harus dilandasi oleh hubungan biologis, mungkin ada baiknya disertakan tafsiran Jakob Van Bruggen terhadap Markus 3:31-35 di sini. Van Bruggen berkomentar bahwa respons Yesus bahwa keluarga-Nya adalah orang-orang yang melakukan kehendak Allah ketika Ia diberitahu mengenai kunjungan ibu dan saudarasaudara-Nya bukan sekadar kiasan melainkan bahwa 'para murid benar-benar adalah saudara-saudara-Nya'. Selanjutnya Van Bruggen menulis, 'Ikatan kekeluargaan ini bukan ikatan darah yang terwujud lewat kelahiran, melainkan ikatan yang terjadi oleh kelahiran kembali. ... Sang Bapa ingin agar semua orang mendengarkan Anak ini, sedangkan Sang Anak menerima mereka dalam nama Allah sebagai saudaraNya' (Markus: Injil menurut Petrus, terj. Th. van den End, dkk. [Jakarta: BPK Gunung Mulia, 2006], 146147). 
radikalitas komitmen terhadap keluarga yang baru dibentuk-Nya yang dilandasi oleh motif nazar seorang nazir. Singkatnya, sebagaimana yang ditulis Bockmuehl, "Mereka yang telah dikhususkan sepenuhnya bagi Allah memiliki hal yang lebih penting untuk dilakukan" melampaui tanggung jawab mereka terhadap kerabat biologis mereka. ${ }^{69}$

Penafsir lain, Crossley, juga berpendapat senada dengan Bockmuehl yang melihat motif kenaziran di balik respons Yesus. Namun lebih dari itu, Crossley berupaya memperlihatkan latar belakang historis untuk menunjang motif ikatan kekerabatan biologis yang sudah disinggung Bockmuehl. Dalam bukunya mengenai PB dan Taurat, Crossley mendiskusikan mengenai respons Yesus terhadap murid yang meminta ijin untuk menguburkan ayahnya. Seperti Bockmuehl, Crossley juga percaya bahwa motif kenaziran mestinya mendapat perhatian kita untuk menafsirkan respons ini. Kontribusi Crossley untuk penafsiran ini adalah investigasinya terhadap konsep "kerabat fiktif" (fictive kinship) dalam komunitas Qumran. Komunitas yang dikenal juga dengan sebutan Essene ini memang memandang penting hubungan kekerabatan biologis dan aturan agar seorang pria Yahudi memiliki seorang istri. $^{70}$ Namun karena

\footnotetext{
${ }^{69}$ Bockmuehl, “'Let the Dead Bury Their Dead' (Matt. 8:22/Luke 9:60): Jesus and the Halakhah" [versi online]. Barton juga memahami respons Yesus sebagai sebuah respons yang melegitimasi kekerabatan Kristiani melampaui kekerabatan biologis. Dan itu berarti, Matius sedang menekankan mengenai otoritas Yesus untuk menuntut komitmen tertinggi dari para pengikut-Nya (Discipleship and Family Ties in Mark and Matthew, 154).

${ }^{70}$ Pada periode Yudaisme Rabbinik, pentingnya pernikahan bagi seorang pria Yahudi terkandung dalam kritikan terhadap rabi Simeon ben Azzai karena ia tidak menikah, demikian: 'Engkau [Simeon ben Azzai] berkhotbah dengan sangat baik, namun tidak mempraktikkan apa yang engkau khotbahkan' (b. Yeb. 63b). Kritikan ini mengasumsikan pentingnya pernikahan bagi seorang pria Yahudi karena bagi mereka pernikahan merupakan suatu keharusan teologis. Bila seorang pria Yahudi tidak menikah, maka ia dianggap merendahkan signifikansi kekerabatan, dan dengan demikian merendahkan mandat Allah (kecuali para nazir). Menjawab kritikan ini, rabbi Simeon ben
}

mereka sangat anti terhadap godaan percabulan yang dilakukan para wanita, maka mereka memutuskan untuk tidak menikah (setidaknya mayoritas di antara mereka). Untuk menunjang praktik ini, sebagaimana yang ditulis oleh Yosefus, mereka membentuk kekerabatan yang baru yang dilandasi komitmen terhadap sesama anggota komunitas itu tanpa harus dihubungkan dengan relasi biologis (War. 2.119-122; Ant. 18.18-22). Hubungan kekerabatan tanpa hubungan biologis inilah yang disebut Crossley sebagai "kerabat fiktif". Menurutnya, konsep kerabat fiktif yang dipraktikkan dalam komunitas Qumran ini memainkan peranan penting dalam ajaran Paulus mengenai kesatuan Yahudi dan non Yahudi (Rm. 9-11) termasuk tuntutan Yesus akan radikalitas komitmen para pengikut-Nya terhadap Dia, salah satunya yang terdapat dalam respons Yesus terhadap murid tersebut. $^{71}$

\section{KOMENTAR EVALUATIF}

Sebelum beralih membahas tentang pandangan yang saya anut, saya perlu memberikan komentar evaluatif singkat terhadap pandangan-pandangan di atas.

Saya melihat bahwa hampir semua pandangan di atas (kecuali pandangan C.1.a) mengasumsikan bahwa ayah sang murid itu baru saja meninggal, walau tidak semuanya memberi pernyataan eksplisit terhadap asumsi ini. Itulah sebabnya, para penganut pandangan-pandangan di atas merasa perlu memberikan alasan untuk respons Yesus demi mengantisipasi implikasinya yaitu ketidakkonsistenan Yesus terhadap perintah PL untuk mengurus secara layak jenasah orangtua yang meninggal. Persoalan mendasar dari pandangan ini adalah ketidakmungkinan logis dan psikologisnya. Mungkinkah seorang Yahudi yang sadar betul akan tanggung jawabnya menguburkan secara layak orangtuanya yang meninggal masih berdiri di situ guna mendapat ijin Yesus? Bahkan dalam

Azzai berkata: 'Jiwaku mengasihi Taurat. Dunia dapat terus dipelihara oleh orang lain' (b. Yeb. 63b).

${ }^{71}$ Crossley, The New Testament and the Jewish Law, 92-94. 
lingkungan orang-orang yang tidak terindoktrinasi dengan tuntutan Taurat tersebut pun rasanya sulit membayangkan ada seorang anak yang tidak segera kembali ke rumah bila mendengar kabar bahwa ayahnya baru saja meninggal. Ketidakmungkinan ini ditegaskan oleh Craig S. Keener demikian: "Pada masa Yesus, seorang anak akan sesegera mungkin kembali ke rumah tatkala mendengar kabar mengenai kematian ayahnya, dan tidak akan menundanya untuk berbicara dengan Yesus...". ${ }^{72}$ Dalam buku tafsirannya, Keener mengulangi ketidakmungkinan itu dengan merujuk kepada tradisi Yahudi pada waktu itu. Ia menyebutkan bahwa segera sesudah seseorang meninggal, para peratap akan segera berkumpul, para pengurus jenasah akan mempersiapkan jenasah itu untuk sesegera mungkin dikuburkan (bnd. Mat. 27:59-60; Mrk. 5:35, 38; Luk. 7:12) ${ }^{73}$ Tradisi seperti ini tidak akan menyisakan banyak waktu bagi salah seorang kerabat dekat untuk berdiskusi terlebih dahulu dengan salah seorang rabbi mengenai hadir atau tidaknya ia dalam acara penguburan itu. ${ }^{74}$

Selanjutnya, pandangan C.1.a di atas memiliki peluang untuk dipertimbangkan, namun respons Yesus tanpaknya lebih masuk akal untuk dianggap mengasumsikan bahwa ayah sang murid itu sudah meninggal. ${ }^{75}$ Ada dua argumen yang penulis pertimbangkan

72 Craig S. Keener, "Matthew's Missiology: Making Disciples of the Nations (Matthew 28:19-20)," in AJPS 12:1 (2009): 17.

${ }^{73}$ Mengenai tata cara pengurusan jenasah dan tradisi ratapan bagi orang mati dalam PL, lih. Harry Syssling, "Lament at the Departure of a Sage: Funeral Songs for Great Scholars as Recorded in Rabbinic Literature," in Studies in Hebrew Literature and Jewish Culture Presented to Albert van der Heide on the Occasion of His Sixty-Five Birthday, eds. Martin F.J. Baasten and Reinier Munk (Amsterdam Studies in Jewish Thought, Vol. 12; Dordrecht: Springer, 2007), 81-84.

${ }^{74}$ Keener, The Gospel of Matthew: A SocioRhetorical Commentary, 275.

75 Keener sendiri mempertimbangkan kemungkinan untuk menerima pandangan B.1.a, namun ia lebih condong kepada pandangan yang akan saya ulas pada poin selanjutnya (The Gospel of Matthew: A Socio-Rhetorical Commentary, 275); bnd. Keener, "Matthew's Missiology: Making Disciples of the Nations (Matthew 28:19-20)," 17. untuk klaim ini, yaitu: pertama, bila ayah sang murid itu masih hidup, sementara Yesus menolak usulan penundaannya demi mengurusi ayahnya, maka respons Yesus itu akan berkontradiksi dengan kecaman-Nya sendiri terhadap orang-orang Yahudi dalam Markus 7:9-13; dan kedua, kontruksi kalimat Yunani dari respons Yesus [“...biarlah orangorang mati menguburkan orang-orang mati mereka sendiri" - terj. literal], tidak mengindikasikan nuansa hipotetis-futuristik: "kalau nanti ia meninggal". Respons ini berbicara tentang orang mati, bukan orang yang akan mati. Itulah sebabnya, kita perlu mempertimbangkan pandangan alternatif yang akan diulas berikut ini. ${ }^{76}$

\section{TRADISI PENGUBURAN YAHUDI}

Telah dijelaskan sebelumnya bahwa masa perkabungan Yahudi berlangsung dalam tiga tahap, yaitu: a) perkabungan selama seminggu; b) perkabungan selama satu bulan; dan c) perkabungan selama satu tahun. Tahapan-tahapan perkabungan ini terhitung sejak hari meninggalnya seseorang dan dibedakan berdasarkan intensitas keterlibatan kerabat terdekatnya dengan urusan-urusan dalam kehidupan normal sehari-hari dan ketergabungan keluarga besar dalam tahapantahapan perkabungan tersebut. Hal yang perlu dijelaskan lebih lanjut adalah praktik penguburan yang berhubungan dengan penentuan masa perkabungan hingga satu tahun.

\section{Praktik Liqut 'Azamot atau Ossilegium}

Pada masa Yesus, dunia Greco-Roman umumnya mempraktikkan kremasi (Lat. crematus) bagi orang yang meninggal, walau adakalanya mereka juga mempraktikkan penguburan. Di pihak lain, praktik penguburan $^{77}$ merupakan sesuatu yang dilakukan

${ }^{76}$ Mengenai keberatan terhadap retroversi dan resistensi terhadap Taurat, lih. Bockmuehl, "'Let the Dead Bury Their Dead' (Matt. 8:22/Luke 9:60): Jesus and the Halakhah" [versi online]; mengenai keberatan terhadap motif nazir, lih. Schreiner, New Testament Theology: Magnifying God in Christ, 626.

77 Mengenai beragam terminologi Ibrani, Aram, dan Yunani yang digunakan untuk 'kubur' yang menggambarkan praktik penguburan Yahudi, lih. Craig 
secara konsisten di kalangan orang-orang Yahudi. $^{78}$

Orang-orang Yahudi mempraktikkan dua tahap penguburan: (1) penguburan yang pertama (primary burial) dilakukan sesegera mungkin pada hari yang sama ketika seseorang meninggal. Pada masa Yesus, atas pengaruh dari Hellenisme, orang-orang Yahudi meletakkan jasad yang telah dikafani dalam loculus atau arcosolium. ${ }^{79}$ (2) Setelah genap satu tahun ketika daging jenasah tersebut telah hancur dan yang tersisa hanya tulang-belulangnya, kerabat terdekat orang yang sudah meninggal itu akan mengambil tulang-belulang tersebut dan menempatkannya dalam sebuah osuari. ${ }^{80}$ Inilah yang disebut dengan liqut 'azamot ("mengumpulkan tulang-tulang") atau ossilegium (berasal dari gabungan kata $o s$ - "tulang" dan lego "mengumpulkan" dalam bahasa Latin; penguburan kedua; secondary burial). ${ }^{81}$

A. Evans, Jesus and the Ossuaries: What the Burial Practices Reveal about the Beginnings of Christianity (Waco, Texas: Baylor University Press, 2003), 7-12; juga Pieter W. van der Horst, Ancient Jewish Epitaphs: An Introductory Survey of a Millennium of Jewish Funerary Epigraphy (300 BCE - 700 CE) (Kampen: Kok Pharos Publishing House, 1991), 41-44.

${ }^{78}$ Evans, Jesus and the Ossuaries, 26.

${ }^{79}$ Loculus adalah sebuah kata bahasa Latin yang berarti 'tempat kecil'. Kata ini digunakan untuk sebuah cerukan arsitektur dalam katakombe (kuburan bawah tanah) sebagai tempat untuk meletakkan jenasah. Kadang-kadang mereka menutup pintu loculus dengan sebuah pahatan berbentuk kepingan (lih. Katherine M.D. Dunbabin, The Roman Banquet: Images of Conviviality [Cambridge: Cambridge University Press, 2003], 254. Arcosolium adalah kata bahasa Latin yang digunakan untuk sebuah cerukan berbentuk lengkung yang dipahat pada dinding katakombe untuk dijadikan tempat peletakkan jenasah (lih. McCane, "Burial Practices, Jewish" [software version]).

${ }^{80}$ Istilah osuari tidak digunakan dalam Alkitab. Namun, seperti yang dikemukakan Evans, istilah-istilah lain dalam Alkitab yang berarti "peti mati", di kemudian hari digunakan juga untuk merujuk kepada osuari. Selain itu, perlu ditambahkan pula bahwa tradisi penggunaan osuari bukan hanya terdapat di Yerusalem, melainkan juga terdapat di lingkungan orang-orang Yahudi yang tinggal di Aleksandira, Karthago, dan Spanyol (lih. Jesus and the Ossuaries, 8-9, 28).

${ }^{81}$ Evans, Jesus and the Ossuaries, 26; McCane, "Burial Practices, Jewish" [software version]; L.Y. Rahmani, A Catalogue of Jewish Ossuaries in the
Menurut Evans, praktik ossilegium telah dikenal dalam masa PL (bnd. Kej. 25:8, 17; 49:29-33; Hak. 2:10; 2Sam. 21:13-14; 1Raj. 13:22; 2Raj. 9:28; 22:20), diteruskan pada masa Intertestamental, dan bahkan dipraktikkan juga dalam Komunitas Qumran, ${ }^{82}$ walau mungkin dalam detail ritual yang variatif. ${ }^{83}$ Yang jelas, ossilegium merupakan praktik yang sangat umum pada masa Yesus. ${ }^{84}$

Sebelum periode Intertestamental, tidak terlalu jelas alasan yang melatarbelakangi praktik ossilegium. Mungkin saja praktik ossilegium dilakukan karena telah beredar konsep bahwa orang yang sudah meninggal tidak benar-benar terpisah dari dunia ini tetapi dalam taraf tertentu masih memengaruhinya. Evans melihat kemungkinan bahwa konsep inilah yang menjadi latar belakang yang baik untuk memahami visi Yehezkiel mengenai tulang-tulang yang kering (Yeh. 37). ${ }^{85}$ Pada masa Hassidim (abad kedua SM), seperti yang diteliti oleh Rahmani, praktik ossilegium mulai diberi muatan teologis yang jelas, khususnya berhubungan dengan doktrin afterlife (kehidupan sesudah kematian) dan doktrin kebangkitan tubuh. Konsep teologis ini secara eksplisit tertera dalam Daniel 12:2 dan literatur Yahudi Intertestamental (mis. 2Mak. 7; 12:38-45; 14:46). Menurut Yosefus, seperti yang disebutkan Rahmani, orangorang Farisi pun menerima doktrin ini, kecuali

Collections of the State of Israel (Jerusalem: The Israel Academy of Science and Humanities, 1994), 53.

${ }^{82}$ Evans, Jesus and the Ossuaries, 27-28.

83 Rahmani menyatakan bahwa kita harus membedakan antara ossilegium yang dipraktikkan pada masa sebelumnya dengan yang dipraktikkan pada periode Intertestamental (lih. A Catalogue of Jewish Ossuaries in the Collections of the State of Israel, 53. Selain itu, atas dasar ekskavasi arkeologis, Rachel Hachlili memperlihatkan variasi ritus penguburan yang terdapat di Yerusalem, Yerikho, dan Komunitas Qumran. Untuk detailnya, lih. Jewish Funerary Customs, Practices and Rites in the Second Temple Period (Leiden: Brill, 2005), 450-516. Hal yang serupa dalam hasil riset Hachlili ini adalah bahwa terdapat praktik ossilegium dalam ketiga area ekskavasi tersebut.

${ }^{84}$ Rene A. Lopez, "Does the Jesus Family Tomb Disproved His Physical Resurrection?", in Bibliotheca Sacra 165 (October - December 2008): 428.

${ }^{85}$ Evans, Jesus and the Ossuaries, 28. 
orang-orang Zaduki. ${ }^{86}$ Komunitas Qumran, walau menerima doktrin ini, namun percaya bahwa hanya jiwa yang bersifat imortal. Menjelang akhir periode Intertestamental, doktrin ini telah diterima secara umum dalam kalangan Yahudi. ${ }^{87}$ Dalam konteks ini, Ossilegium dilihat sebagai "metode yang paling dapat diterima untuk pemeliharaan sebuah jasad untuk kebangkitan" ${ }^{88}$ Rahmani juga menyebutkan sebuah alasan lain berkenaan dengan praktik ossilegium yang terdapat dalam Talmud Yerusalem. Dikatakan bahwa seorang anak berdukacita semasa ia belum mengumpulkan kembali tulang-tulang orangtuanya, namun setelah melakukannya, ia akan bersukacita (TJ MK 80c). Konteks dari lontaran ini adalah keputusan pengadilan bagi para kriminal agar tidak dikuburkan dalam kuburan keluarga pada saat penguburan pertama. Para kriminal tersebut baru boleh dikumpulkan bersama nenek moyang mereka yang telah meninggal pada saat penguburan kedua (M. Sanh. 6:5-6; bnd. Tos. Sanh. 9:89). Selanjutnya, pada masa antara akhir abad pertama SM dan awal abad ketiga $M$, berkembang pemahaman bahwa dosa yang telah mengkontaminasi seluruh manusia dapat dibersihkan pada masa antara penguburan pertama hingga penguburan kedua. ${ }^{89} \mathrm{Jadi}$, bisa dikatakan bahwa penguburan kedua menandai berakhirnya stigma terhukum bagi para kriminal yang sudah meninggal dan dianggap juga sebagai penanda berakhirnya proses pembersihan terhadap dosa yang telah mengkontaminasi seseorang yang sudah meninggal itu semasa ia hidup.

Itulah sebabnya, sejumlah penafsir berpendapat bahwa permohonan ijin sang murid itu untuk menguburkan ayahnya, merujuk kepada praktik ossilegium atau

86 Praktik ossilegium di kalangan Zaduki dilakukan mungkin karena alasan kultural semata (lih. Lopez, "Does the Jesus Family Tomb Disproved His Physical Resurrection?", 429).

${ }^{87}$ Rahmani, A Catalogue of Jewish Ossuaries in the Collections of the State of Israel, 53-54.

${ }^{88}$ Rahmani, A Catalogue of Jewish Ossuaries in the Collections of the State of Israel, 54.

${ }^{89}$ Rahmani, A Catalogue of Jewish Ossuaries in the Collections of the State of Israel, 54. praktik penguburan kedua. ${ }^{90}$ Penafsir yang pertama kali mengemukakan pandangan ini adalah Eric M. Meyers. ${ }^{91}$ Umumnya, para penafsir yang menganut pandangan ini

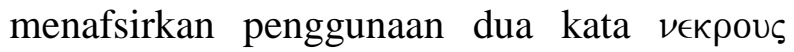
dalam respons Yesus sama-sama merujuk kepada orang-orang yang mati secara fisik. ${ }^{92}$ Pandangan ini terindikasi dari penggunaan kata $\dot{\epsilon} \alpha u \tau \hat{\omega} \nu$ yang menyejajarkan makna

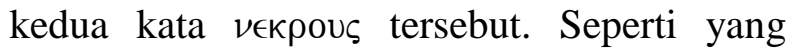
sudah dijelaskan sebelumnya, respons Yesus yang bernada penolakkan ini bisa jadi dilontarkan karena "distorsi" konsep pembersihan dosa (semacam konsep purgatori) yang mulai dipopularkan oleh para rabbi berkenaan dengan praktik ossilegium.

\section{Menjawab Keberatan: Probabilitas Abduktif}

Atas dasar argumen-argumen pada komentar evaluatif di atas, saya menerima pandangan bahwa permohonan ijin sang murid itu merujuk kepada praktik ossilegium. Sang murid itu mengajukan penundaan untuk mengikut Yesus sesegera mungkin karena ingin menuntaskan tanggung jawabnya mengumpulkan tulang-tulang ayahnya yang sudah meninggal. Pertanyaannya, mengapa

${ }^{90}$ Antara lain: Evans, Jesus and the Ossuaries, 13; McCane, "Burial Practices, Jewish" [software version]; Keener, The Gospel of Matthew: A SocioRhetorical Commentary, 275); bnd. Keener, "Matthew's Missiology: Making Disciples of the Nations (Matthew 28:19-20)," 17; Joel B. Green, The Gospel of Luke (NICNT; Grand Rapids, Michigan: Eerdmans, 1997), 408-409.

${ }^{91}$ Informasi ini saya dapatkan dari Bockmuehl yang merujuk kepada tulisan E.M. Meyers, "Jewish Ossuaries: Reburial and Rebirth: Secondary Burials in Their Ancient Near Eastern Setting," in Bib. et Or. 24 (Rome: Biblical Institute, 1971). Sebenarnya, satu tahun sebelum Meyers mempublikasikan tulisan ini, ia telah menulis sebuah artikel mengenai praktik ossilegium: E. M. Meyers, "Secondary Burials in Palestine" in The Biblical Archeologist 33 (1970).

${ }^{92}$ Green, The Gospel of Luke, 408-409; Evans, Jesus and the Ossuaries, 13. Perlu diinformasikan bahwa sebelumnya Evans menganut pandangan bahwa respons Yesus merujuk kepada dua macam orang mati, yaitu orang-orang yang mati secara spiritual dan fisik, lih. Craig A. Evans, Luke (Understanding the Bible Commentary Series; Grand Rapids, Michigan: Baker, 1980). 
tidak semua penafsir menerima pandangan ini?

Menurut saya, keberatan tersulit untuk pandangan ini terletak pada konstruksi semantik dari kata-kata sang murid tersebut. Sang murid tersebut meminta ijin untuk menguburkan ayahnya, bukan tulang-tulang ayahnya. Itulah sebabnya, Bockmuehl menyatakan bahwa pandangan ini tidak meyakinkannya karena terminologi yang digunakan untuk ossilegium selalu "mengumpulkan [dan menguburkan] tulangtulang" bukan "menguburkan seseorang". 93 Kelihatannya keberatan Bockmuehl cukup berdasar karena ketika saya membaca tulisan Rahmani, di sana disertakan, misalnya, dua sumber Yahudi yang mengafirmasinya. Rahmani mengutip pesan rabbi Eleazar bar Zadok kepada anaknya: “...kuburkan aku terlebih dahulu [penguburan pertama].... Pada masanya, kumpulkan tulang-tulangku dan tempatkan mereka [tulang-tulangku] dalam osuari [penguburan kedua]..." (Sem. 12:9; huruf miring dan keterangan tambahan dari saya). ${ }^{94}$ Selanjutnya, Rahmani juga merujuk kepada Talmud Yerusalem yang menyatakan, "Seorang pria mengumpulkan tulang-tulang ayah dan ibunya..." (TJ MK 80c; huruf miring dari saya). ${ }^{95}$ Menariknya, bahkan data PL dan literatur-literatur Yahudi yang dirujuk Evans sebagai bukti bahwa ossilegium telah dipraktikkan sejak masa PL pun menggunakan konstruksi semantik seperti isi keberatan Bockmuehl. ${ }^{96}$

Keberatan di atas, harus diakui, sulit untuk ditemukan data tekstual yang secara langsung "menangkalnya". Meski demikian, dalam eksegesis keberatan di atas pada dasarnya mesti dinilai tidak esensial. Makna teks tidak ditentukan, terutama, oleh konsistensi konstruksi semantiknya dengan konteks tekstual lainnya, sebagaimana yang

${ }^{93}$ Bockmuehl, “'Let the Dead Bury Their Dead' (Matt. 8:22/Luke 9:60): Jesus and the Halakhah" [versi online]. Keberatan ini dikemukakan Bockmuehl pada catatan kaki no. 35 dalam artikelnya.

${ }^{94}$ Rahmani, A Catalogue of Jewish Ossuaries in the Collections of the State of Israel, 53.

${ }^{95}$ Rahmani, A Catalogue of Jewish Ossuaries in the Collections of the State of Israel, 54.

${ }^{96}$ Evans, Jesus and the Ossuaries, 27-28. dipresuposisikan dalam keberatan di atas. ${ }^{97}$ Prinsip yang sangat mendasar dalam eksegesis adalah bahwa makna teks mesti ditentukan oleh konteksnya. Implikasinya, praktik ossilegium tidak dapat dieliminasi dari arena eksegesis hanya karena ia menggunakan konstruksi semantik yang tidak paralel dengan konstuksi semantik yang umumnya digunakan untuk praktik tersebut. Praktik ini hanya dapat ditolak secara meyakinkan dari arena eksegesis bila seseorang mampu memperlihatkan ketidakmungkinannya dari konteksnya. Dan sejauh yang saya ketahui, tidak satu pun penafsir yang mengajukan keberatan terhadap pandangan ini berdasarkan konteksnya. Sebaliknya, konteksnya pun tidak mengindikasikan secara jelas mengenai praktik ossilegium sebagai latar kulturalnya, walau bukan tidak ada sama sekali. Penggunaan kata $\dot{\epsilon} \alpha \nu \tau \hat{\omega} \nu$ dalam respons Yesus tampaknya menempatkan dua kata toùs $\nu \in \kappa \rho o u ̀ s ~ d a l a m$ pengertian yang sejajar. Kembali kepada komentar-komentar evaluatif saya di atas, bila kita menggunakan probabilitas abduktif, ${ }^{98}$ maka praktik ossilegium lebih memungkinkan untuk diajukan sebagai latar kultural di balik permohonan ijin murid tersebut. ${ }^{99}$

${ }^{97}$ Keberatan di atas mempresuposisikan bahwa konstruksi "kumpulkan dan kuburkan tulang-tulang" merupakan konstruksi teknis yang mesti digunakan apabila seseorang ingin berbicara tentang praktik ossilegium. Presuposisi ini sangat dekat dengan 'asumsi-asumsi yang keliru mengenai arti teknis' sebagaimana yang telah dibahas oleh: D.A. Carson, Kesalahan-kesalahan Eksegetis, terj. Lanna Wahyuni (Surabaya: Momentum, 2006), 51-55.

${ }_{98}$ Penalaran abduktif adalah proses penyimpulan berdasarkan perbandingan mengenai peluang yang lebih memungkinkan dari sebuah pandangan atau situasi dibandingkan dengan pandangan-pandangan atau situasi-situasi lainnya. Misalnya, untuk mengabduksi a dibandingkan $\mathrm{b}$, meliputi penetapan kesimpulan berdasarkan kecukupan bukti/logis dari a ketimbang b.

${ }^{99}$ Dalam komentar evaluatif di atas, saya sudah menegaskan bahwa baik pandangan C.1.a maupun pandangan C.1.b sangat mungkin tidak meyakinkan untuk dianut. Sementara itu, berdasarkan respons Yesus, kita mestinya percaya bahwa memang ayah sang murid tersebut telah meninggal. Itulah sebabnya, ketidakmungkinan-ketidakmungkinan ini lebih cenderung mengarahkan kita kepada pandangan E.1. 


\section{SIGNIFIKANSI STUDI INI DAN KESIMPULAN}

Kontribusi saya untuk isu ini mungkin tidak terlalu banyak. Pandangan yang saya angkat sebagai pandangan representatif pun bukanlah sebuah pandangan yang baru. Meski demikian, setahu saya, artikel ini memuat survei eksegetis yang terbilang cukup lengkap. ${ }^{100}$ Dalam melakukan hal ini, saya berharap agar pokok-pokok argumen saya dipertimbangkan secara memadai berdasarkan deskripsi yang saya upayakan setepat mungkin mengenai berbagai pandangan yang ada. Hal ini juga berarti bahwa saya tidak sekadar mengklaim sebuah pandangan tanpa mempertimbangkannya dalam hubungan dengan pandangan-pandangan lainnya. Selain itu, Anda yang membaca artikel ini pun dapat tertolong oleh survei eksegetis yang cukup lengkap ini untuk memetakan posisi eksegetis Anda.

Lontaran saya dalam paragraf di atas sengaja dilakukan karena sejauh yang saya amati, mayoritas [bila tidak semua] buku tafsiran Injil Matius dan Injil Lukas yang beredar di Indonesia (Barclay, de Heer, Henry) ${ }^{101}$ menganut pandangan bahwa ayah sang murid tersebut belum meninggal dan permohonan ijinnya dilakukan demi mengurusi ayahnya yang masih hidup itu hingga meninggal. Secara kualitatif, hal ini merupakan indikator bahwa pandangan ini merupakan pandangan mayoritas di Indonesia. ${ }^{102}$ Dengan mempertahankan

${ }^{100}$ Sampai dengan komposisi final dari artikel ini, saya belum menemukan sebuah artikel mengenai isu yang saya bahas ini yang memuat survei eksegetis selengkap yang saya kemukakan dalam artikel ini.

101 R.T. France [Injil Matius] dan Ian Howard Marshal [Injil Lukas] dalam Tafsiran Alkitab Masa Kini 3 tidak menyatakan posisi mereka secara jelas berkenaan dengan permohonan ijin sang murid tersebut. Meski demikian, dari tafsiran mereka bahwa respons Yesus merujuk kepada "orang-orang yang mati secara spiritual menguburkan orang-orang yang mati secara fisik", kita bisa menduga bahwa mereka pun mempresuposisikan pandangan di atas. Sebagai informasi, Tafsiran Alkitab Masa Kini 3 adalah terjemahan dari New Bible Commentary.

${ }^{102}$ Saya menyadari bahwa dunia ini telah menjadi seperti sebuah global village di mana pertukaran informasi bukan lagi terbatas pada peredaran literatur. sebuah pandangan yang agak "asing" di Indonesia, saya berharap artikel ini dapat memicu diskusi lebih lanjut untuk memperkaya khasanah dunia eksegesis PB, khususnya eksegesis terhadap Matius 8:2122/Lukas 9:59-60 di Indonesia.

Hal yang agak disayangkan namun sebenarnya merupakan sebuah kejujuran intelektual adalah bahwa saya tidak dapat memberikan sebuah kesimpulan yang benarbenar pasti mengenai latar kultural dari permohonan ijin sang murid tersebut. Meski demikian, berdasarkan uraian di atas, saya percaya bahwa kemungkinan besar sang murid tersebut meminta ijin untuk menyelesaikan tanggung jawabnya mengumpulkan tulang-tulang ayahnya yang telah meninggal (ossilegium). Yesus menolak maksud sang murid itu karena Ia melihat bahwa praktik ossilegium telah terdistorsi oleh konsep teologis yang keliru. Praktik ossilegium yang telah terboncengi oleh semacam doktrin purgatori itu tidak dapat tidak harus ditolak karena pembasuhan dosa hanya terjadi melalui pengorbanan Yesus (bnd. Kis. 4:12; Ef. 2:9-9; Ibr. 9:22, 26). Inilah inti berita Kerajaan Allah yang sesugguhnya. Itulah sebabnya, Yesus memanggil sang murid itu untuk mengikut Dia dengan sebuah tanggung jawab yang lebih otentik: memproklamirkan kerajaan Allah (Luk. 9:60). ${ }^{103}$

Meski demikian, indikasi yang saya amati di atas memang tidak dapat sepenuhnya diabaikan. Buku-buku tafsiran yang beredar dalam bahasa Indonesia di Indonesia memang semuanya menganut pandangan ini. Dan dengan mempertimbangkan keterbatasan kemampuan berbahasa asing, pengamatan saya di atas tidak sepenuhnya dapat diabaikan. Selain itu, sebagai seorang akademisi, saya mengetahui persis bahwa biasanya pandangan yang dianggap reliabel untuk dianut adalah pandangan yang terpublikasi dalam bentuk literatur.

103 John Nolland menyatakan bahwa "Memberitakan Kerajaan Allah sering muncul dalam tulisan Lukas walau dengan menggunakan kata kerja yang berbeda $[4: 43 ; 8: 1 ; 16: 16 ; 9: 2$; Kis. $8: 12$; 28:31; kata kerja yang digunakan adalah diaggevlein; kata kerja ini digunakan tanpa frasa 'Kerajaan Allah' dalam Kis. 21:26]' (Luke 9:21-18:34, [Software version of WBC Vol. 35b; Dallas, Texas: Word Books, Publisher, 1998]). 


\section{KEPUSTAKAAN}

Archer, Jr., Gleason L., Encyclopedia of Bible Difficulties (Grand Rapids, Michigan: Zondervan, 1982).

Augustine, "Letters of St. Augustine: To Evodius Ch. VI.21 [414 AD]," in Nicene and Post-Nicene Fathers Series I, Vol. 1, ed. Philip Scaff, trans. J.G. Gunningham (Grand Rapids, Michigan/Edinburgh: Eerdmans/T. \& T. Clark, 1886).

Bailey, Kenneth E., Through Peasant Eyes (Grand Rapids, Michigan: Eerdmans, 1980).

Barclay, William, The Daily Study of the Bible: The Gospel of Matthew Volume 1 Chapter 1-10 (Philadelphia: The Westminster Press, 1958).

Barton, Stephen C., "The Relativisation of Family Ties in the Jewish and GraecoRoman Traditions," in Constructing Early Christian Family: Family as Social Reality and Metaphor, ed. Halvor Moxnes (London: Routledge, 1997).

Basser, Herbert W., "Let the Dead Bury Their Dead: Rhetorical Features of Rabbinic and New Testament Literature," in Approaches to Ancient Judaism, eds. Herbert W. Basser and S. Fishbane (New Series, Vol. 5; Atlanta: Scholar Press, 1989).

Black, Matthew, "Let the Dead Bury Their Dead," in The Expository Times 62 (1949-1950).

Bockmuehl, Markus, "'Let the Dead Bury Their Dead' (Matt. 8:22/Luke 9:60): Jesus and the Halakhah," in Journal of Theological Studies (1998). http://www.accessmy library.com/article1G1-21263299/let-dead-bury-their.html, diakses tanggal 7 Maret 2013.

Calvin, Yohanes, A Harmony of the Gospels: Matthew, Mark and Luke, Vol. I, trans. A.W. Morrison, eds. David W. Torrance and Thomas F. Torrance (Calvin's New Testament Commentaries; reprinted edition; Grand Rapids, Michigan: Eerdmans, 1989).
Charles, R. H. The Apocrypha and Pseudopigrapha of the Old Testament in English: Vol. I - Apocrypha (Oxford: Clarendon Press, 1913).

Chrysostom, John, "Homilies of St. John Chrysostom on the Gospel of St. Matthew: Homily XXVII," in Nicene and Post-Nicene Fathers, Series I, Vol. 10, ed. Philip Scaff, trans. Sir George Prevort Barones, revised by M.B. Riddle (Grand Rapids, Michigan/Edinburgh: Eerdmans, T. \& T. Clark, 1888).

Clemens of Alexandria, "The Instructor Book III, Chapter X," in The Ante-Nicene Fathers Vol. 2, trans. Philip Schaff, eds. Alexander Roberts and James Donaldson (Grand Rapids, Michigan: Christian Classics Ethereal Library, 1819-1893).

Crossley, James G., The New Testament and the Jewish Law: A Guide for the Perplexed (New York: T. \& T. Clark International, 2010).

Cyprian, "The Treatises of Cyprian: 'On the Lord's Prayer', Treatise IV.9," in AnteNicene Fathers Vol. 5, ed. Philip Scaff, trans. Ernest Wallis (Grand Rapids, Michigan: Christian Ethereal Classics Library, 1819-1893).

Davies, W. D. and Dale C. Allison, Jr., A Critical and Exegetical Commentary on the Gospel according to St. Matthew: A Commentary on Matthew 8-18 (ICC; Edinburg: T. \& T. Clark, 2001)

de Heer, J. J., Injil Matius Pasal 1-22 (Jakarta: BPK Gunung Mulia, 2003).

Duling, Dennis C., "The Gospel of Matthew," in The Blackwell Companion to the New Testament, ed. David E. Aune (West Sussex: Willey-Blackwell, 2010).

Dunbabin, Katherine M. D., The Roman Banquet: Images of Conviviality (Cambridge: Cambridge University Press, 2003).

Dunn, James D. G., Christianity in the Making Volume 1: Jesus Remembered (Grand Rapids, Michigan: Eerdmans, 2003).

Evans, Craig A., Jesus and the Ossuaries: What the Burial Practices Reveal about 
the Beginnings of Christianity (Waco, Texas: Baylor University Press, 2003).

Fitzmyer, Joseph A., A Wandering Aramean: Collected Aramaic Essays (Society of Biblical Literatur, Monograph Series 25; Chico, California: Scholars Press, 1979).

France, R. T., The Gospel of Matthew. NICNT (Grand Rapids, Michigan: Eerdmans, 2007).

Matthew. TNTC (Surabaya: Momentum, 2007).

Green, Joel B., The Gospel of Luke (NICNT; Grand Rapids, Michigan: Eerdmans, 1997).

Gundry, Robert H., Matthew: A Commentary on His Handbook of Mixed Church Under Persecution (2 ${ }^{\text {nd }}$ edition; Grand Rapids, Michigan: Eerdmans, 1994).

Hagner, Donald A., Matthew 1-13 (Software Version of WBC, Vol. 33a; Dallas, Texas: Word Books Publishers, 1998).

Hengel, Martin, The Charismatic Leader and His Followers, trans. J.C.G. Greig, ed. J. Riches $\left(2^{\text {nd }}\right.$ edition; Edinburgh: T. \& T. Clark, 1996)

Jeremias, Joachim, New Testament Theology Vol. 1: The Proclamation of Jesus (London: SCM Press, 1971).

Josephus, Flavius, Josephus: The Complete Works (Grand Rapids, Michigan: Christian Classics Ethereal Library, n.d.).

Kaiser, Jr., Walter C. et al, The Hard Sayings of the Bible (One-volume edition; Downers Grove, Illinois: InterVarsity Press, 1996).

Keener, Craig S., “Matthew's Missiology: Making Disciples of the Nations (Matthew 28:19-20)," in AJPS 12:1 (2009).

., A Commentary on the Gospel of Matthew (Grand Rapids, Michigan: Eerdmans, 1999).

., The Gospel of Matthew: A SocioRhetorical Commentary (Grand Rapids, Michigan: Eerdmans, 2009).

The IVP Bible Background Commentary: New Testament (Downers Grove, Illinois: InterVarsity Press, 1993).
Kohler, Kaufmann, The Origins of Synagogue and the Church (New York: The Macmillan Company, 1929).

Lopez, Rene A., "Does the Jesus Family Tomb Disproved His Physical Resurrection?", in Bibliotheca Sacra 165 (October - December 2008).

M'Neile, Alan Hugh, The Gospel according to St. Matthew (London: Macmillan, 1915).

Manson, Thomas Walter, The Teaching of Jesus: Studies in Its Form and Content (Cambridge: Cambridge University Press, 1967).

McCane, B. R. "Burial Practice, Jewish," in Dictionary of New Testament Background, eds. Craig A. Evans and Stanley E. Porter (Software Version; Downers Grove, Illinois: InterVarsity Press, 2000).

McDaniel, Thomas F., Clarifying More Baffling Bilblical Passages (Narrberth, Pennsylvannia: n.p., 2008). http://tmcdaniel. palmerseminary.edu/CBBP_Chapter_29. $p d f$, diaskes tanggal 7 Maret 2013.

Mounce, Robert C., Matthew (Understanding the Bible Commentary Series; Grand Rapids, Michigan: Baker, 1991).

Rahmani, L. Y., A Catalogue of Jewish Ossuaries in the Collections of the State of Israel (Jerusalem: The Israel Academy of Science and Humanities, 1994)

Sanders, E. P., Jesus and Judaism (Philadelphia: Fortress Press, 1985).

Schreiner, Thomas R., New Testament Theology: Magnifying God in Christ (Grand Rapids, Michigan: Baker Academic, 2008).

Turner, David L., Matthew (BECNT; Grand Rapids, Michigan: Baker Academic, 2008).

van der Horst, Pieter W. Ancient Jewish Epitaphs: An Introductory Survey of a Millennium of Jewish Funerary Epigraphy (300 BCE - $700 \quad C E)$ (Kampen: Kok Pharos Publishing House, 1991). 